\title{
Does Living by the Sword Mean Dying by the Sword?
}

Charles Chernor Jalloh

Florida International University College of Law, charles.jalloh@fiu.edu

Follow this and additional works at: https://ecollections.law.fiu.edu/faculty_publications

Part of the Criminal Law Commons, and the International Law Commons

\section{Recommended Citation}

Charles Chernor Jalloh, Does Living by the Sword Mean Dying by the Sword? , 117 Penn St. L. Rev. 707 (2013).

Available at: https://ecollections.law.fiu.edu/faculty_publications/254

This Article is brought to you for free and open access by the Faculty Scholarship at eCollections. It has been accepted for inclusion in Faculty Publications by an authorized administrator of eCollections. For more information, please contact lisdavis@fiu.edu. 


\section{HEINONLINE}

Citation: 117 Penn St. L. Rev. 707 2012-2013

Provided by:

FIU College of Law

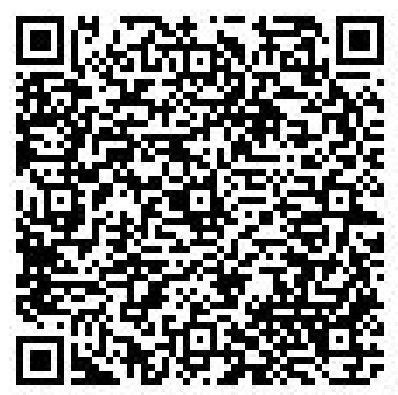

Content downloaded/printed from $\underline{\text { HeinOnline }}$

Wed Sep 21 12:30:55 2016

-- Your use of this HeinOnline PDF indicates your acceptance of HeinOnline's Terms and Conditions of the license agreement available at http://heinonline.org/HOL/License

-- The search text of this PDF is generated from uncorrected OCR text.

-- To obtain permission to use this article beyond the scope of your HeinOnline license, please use:

\section{Copyright Information}




\title{
Articles
}

\section{Does Living by the Sword Mean Dying by the Sword?}

\section{Charles Chernor Jalloh*}

\begin{abstract}
This article examines the right to self-representation in international criminal law, and the common challenges posed for judges effectuating that right in international criminal courts. Using a comparative law approach, the paper demonstrates how the interpretation of that right initially borrowed heavily from U.S. common law and later European civil law to address the problems caused by self-representing, disruptive,

* B.A. (Guelph), LL.B., B.C.L. (McGill), M.St. (with distinction) and Chevening Scholar (Oxford); Assistant Professor, University of Pittsburgh School of Law, Pennsylvania, United States of America; former Legal Advisor to the Office of the Principal Defender and court-appointed duty counsel to former Liberian President Charles Taylor, Special Court for Sierra Leone; Associate Legal Officer, International Criminal Tribunal for Rwanda and Visiting Professional, Office of Public Counsel for the Defense, International Criminal Court. E-mail: jallohc@gmail.com.

I am grateful for excellent comments received on an earlier draft from Judge Fausto Pocar, Appeals Chamber, International Criminal Tribunals for former Yugoslavia and Rwanda, and Professor Linda Carter, Pacific McGeorge School of Law. I thank Samuel Derrick, my former research assistant, for his outstanding help, which enabled this paper to come out as quickly as it did. The usual disclaimer as to responsibility for contents and omissions applies. This paper is based on research conducted for an invited contribution to INTERNATIONAL CRIMINAL PROCEDURE (Linda Carter \& Fausto Pocar eds.) (Edward Elgar, forthcoming 2013), in which a version of this article will appear.
\end{abstract}


and uncooperative defendants. Although the right to self-representation is a Sixth Amendment right in U.S. law, and an equally fundamental one in international law, the author contends that this right seems better in theory than in practice. Indeed, since no self-representing defendant in an international penal court has ever succeeded in securing an acquittal, by choosing to represent themselves, defendants who lack the ability, objectivity, and experience needed to raise reasonable doubt in complex criminal trials may unwittingly help pave the prosecution's way to their own convictions.

\section{Table of Contents}

I. INTRODUCTION 708

II. THE RIGHT TO SELF-REPRESENTATION AND THE ROLE OF COUNSEL IN INTERNATIONAL CRIMINAL TRIALS.

A. The Types of Counsel Used by International Courts ................. 711

B. Use of Counsel by the International Tribunals............................. 715

C. Issues that Arise for Self-Representing Defendants and Counsel in International Tribunals

III. COMMON LAW AND CIVIL LAW PERSPECTIVES ON THE RIGHT TO SELF-REPRESENTATION AND APPOINTMENT OF COUNSEL..................... 722

A. Differing Theories about the Purpose of Criminal Trials............ 722

B. Principles Shaping the Use of Counsel in Common Law and Civil Law Systems

IV. APPLICATION OF COMMON LAW AND CIVIL LAW APPROACHES IN THE INTERNATIONAL CRIMINAL TRIBUNALS

A. Should the Court Appoint Counsel for the Defendant or Allow Him to Represent Himself?

B. Should the Court Appoint Standby or Amicus Curiae Counsel?

C. Options upon Removal of the Disruptive Defendants................. 747

V. CONCLUSION 751

\section{INTRODUCTION}

On July 3, 2001, former Yugoslav President Slobodan Milošević, who was on trial for his alleged role in perpetrating international crimes in the Balkans, informed the Trial Chamber of the International Criminal Tribunal for the former Yugoslavia (ICTY) that he did not want a lawyer 
to represent him during future proceedings. ${ }^{1}$ The judges allowed Milošević to continue in this manner, but also appointed amicus curiae to assist the Court. ${ }^{2}$ As Milošević's health began to diminish, the ICTY faced difficult questions regarding if and when to assign counsel to represent the accused and, in so doing, restrict Milošević's right to defend himself. The ICTY's handling of these problems, as well as Milošević's subsequent death before the completion of his trial, thrust unresolved questions of international criminal procedure into the spotlight. ${ }^{3}$

Since then, many defendants before the ICTY and other international criminal courts have tried to follow Milošević's lead and represent themselves. Others, failing to gain permission to continue without legal counsel, have instead attempted to emulate Milošević's other lead to disrupt the trial proceedings as much as possible. The evolving body of international criminal law has responded to these challenges by developing procedures to deal with defendants who want to represent themselves or who create large and continuous disruptions of court proceedings.

This article discusses the various roles played by counsel in international criminal trials in the limited circumstances where defendants choose to represent themselves, be disruptive, or engage in obstructionist behavior. I demonstrate that, much like U.S. criminal law, in international criminal law, accused persons have the fundamental right to represent themselves in person or through legal assistance of their own choosing. That said, while the right to self-representation sounds good in theory, in practice, it is fraught with difficulties. It is a right that defendants before international tribunals should invoke sparingly, if at all, especially considering that these defendants usually stand accused of some of the worst crimes in the legal lexicon.

A review of leading cases shows that, by conveniently borrowing from Anglo-American common law in some cases, and continental European civil law in others, international criminal courts have failed to develop a single or unified approach to defendants' right to selfrepresentation. This lack of uniformity has hindered the accused persons

1. Prosecutor v. Milošević, Case No. IT-99-37-I, Written Note by the Accused, Registry, 3371-72 (Int'l Crim. Trib. for the Former Yugoslavia July 3, 2001); Prosecutor v. Milošević, Case No. IT-99-37-I, Initial Appearance, Transcript, 1-2 (Int'l Crim. Trib. for the Former Yugoslavia July 3, 2001).

2. See generally Prosecutor v. Milošević, Case No. IT-02-54, Order Inviting Designation of Amicus Curiae (Int'l Crim. Trib. for the Former Yugoslavia Aug. 30, 2001) [hereinafter Milošević, Order Inviting Designation of Amicus Curiae].

3. See Joanne Williams, Slobodan Milošević and the Guarantee of SelfRepresentation, 32 BROOK. J. INT'L L. 553, 554-55 (2007). 
who have sought to use, and sometimes abuse, the right for political purposes. I submit that, since no self-representing defendant in an international trial has yet succeeded in securing an acquittal, by choosing to exercise the right to self-representation, even legally trained defendants who lack the objectivity, ability, and experience in challenging prosecution evidence in complex criminal trials may risk helping prosecutors pave the way to their own convictions.

The article proceeds as follows. Part II provides background on the right to self-representation and the role of assigned, standby, and amicus counsel in international criminal proceedings. Part III examines common law and civil law approaches to the right of self-representation. The focus, although not exclusively, is on the U.S. Supreme Court jurisprudence that supplied helpful precedent on how to interpret the right of self-representation in the early international criminal tribunal cases.

Part IV discusses the main circumstances under which national courts using these principles appoint counsel to represent the accused, even against his objections, so long as his conduct threatens to derail the integrity of the trial process. Part IV then assesses how well these principles have been transposed to and applied in international criminal courts. I show that, in national jurisdictions, limited wiggle room is typically afforded to obstructionist defendants bent on undermining their own trials. On the other hand, in some international courts, especially in their early cases, disruptive defendants seem to engage in contumacious conduct without immediately receiving meaningful sanction, such as the logical forfeiture of the right to represent themselves in court. This disruptive behavior has caused unacceptable delays in many important cases and has impelled a shift away from the common law's deference towards an accused person's right to defend himself in person in favor of the civil law approach, which seems less hesitant to curtail the defendant's rights in order to maintain the overall continuity and integrity of the proceedings.

Finally, in Part V, I conclude with key findings and some final observations. I note the general improvement in international criminal tribunals' ability to smoothly handle self-representing, disruptive, or uncooperative defendants. It seems settled that the right to choose whether to be represented by counsel or to appear pro se is an inherent right of the defendant that should never be abrogated. However, the attempts by some high profile accused persons to turn the courtroom into a platform to advance divisive ethnic political agendas, to badger witnesses and victims, and to transform the dignified search for justice into political theater undermines both the legal and moral justifications for the right. If this trend continues, as international criminal law 
matures, the tendency will likely be for the right to be increasingly curtailed over time.

\section{THE RIGHT TO SELF-REPRESENTATION AND THE ROLE OF COUNSEL IN INTERNATIONAL CRIMINAL TRIALS}

\section{A. The Types of Counsel Used by International Courts}

International courts employ three main types of legal counsel as tools to maintain control over proceedings in cases involving uncooperative or disruptive defendants: (1) standby or duty counsel, (2) court-assigned counsel, and (3) amicus curiae. Standby counsel is a lawyer appointed by the court to assist an accused who is asserting the right of self-representation. ${ }^{4}$ This attorney, who may be designated at the court's own initiative, generally assists the defendant in properly preparing and presenting his case by, for example, helping him understand and navigate basic courtroom procedures. ${ }^{5}$ The lawyer is literally on "standby" ready to step in at short notice should the court order him to take over the defense case in exceptional circumstances. For instance, standby counsel may be ordered to step in where the defendant engages in disruptive behavior or other conduct requiring his removal from the courtroom, falls ill for an extended period, or is otherwise unable to continue participating in the proceedings.

The key is that, once appointed, a standby lawyer can only provide assistance if and to the extent requested by the self-representing defendant, who still enjoys the core right and bears primary responsibility to lead and present his own defense. A self-representing accused, including one taking advantage of the assistance offered by standby counsel, may still seek legal advice from a lawyer of his own choosing at his own expense. It seems common in some of the tribunals, where the defendant is indigent, for publicly funded counsel to also be made available to assist the accused acting pro se for interest of justice reasons. This feature is found in various jurisdictions such as the United

4. Although the idea of standby counsel was first discussed in the International Criminal Tribunal for Rwanda, in Prosecutor v. Barayagwiza, Case No. ICTR-97-19-T, Decision on Defense Counsel Motion to Withdraw, $\uparrow$ Tी 18-22 (Nov. 2, 2000) [hereinafter Barayagwiza, Decision on Defense Counsel Motion to Withdraw], a detailed discussion of the concept was later given in the ICTY case of Prosecutor v. Sešelj, Case No. IT-0367-PT, Decision on Prosecution's Motion for Order Appointing Counsel to Assist Vojislav Šešelj with His Defence, Iा 12-30 (Int'l Crim. Trib. for the Former Yugoslavia May 9, 2003) [hereinafter Šešelj, Decision on Prosecution's Motion for Order Appointing Counsel to Assist Vojislav Ššelj with His Defence].

5. See Šěselj, Decision on Prosecution's Motion for Order Appointing Counsel to Assist Vojislav Ššelj with His Defence, supra note 4, ๆ 30. 
States, giving rise to a hybrid type of self-representation with the background assistance and advice of qualified defense counsel or legal researchers.

Another term often used for a specific type of "standby counsel" is "duty counsel." Sometimes, the phrase "duty counsel" is used as short hand reference to a lawyer who may be ordered to provide initial legal advice and assistance to an accused pending the appointment of counsel say following arrest or if the defendant suddenly elects to represent himself. This "duty" includes assisting the suspect with summary procedures, such as during his arraignment, or stepping in to represent the defendant's interest when he is not present in court on his own volition or when the court has ordered his removal.

The duty counsel is typically but not necessarily always a tribunal employee. Where duty counsel is an employed attorney, in a registry defense office or other similar unit, a common challenge that has arisen for international criminal courts is how to separate the double functions of the lawyer in his capacity as an employee administratively reporting to court seniors in the Registry and that of his role as attorney with responsibility only to act in the best interests of his client. Although as a matter of principle, it is obvious that the duty counsel in such cases should only take instructions from his client-whose interests he is sworn to protect to the best of his ability-it is not uncommon that some senior tribunal officials fail to appreciate the need to separate the lawyer's dual functions. That is, it would be generally permissible to address the duty counsel as a subordinate on purely administrative and non-client matters, whereas it is completely unethical to encroach on his role as a legal counselor to the defendant.

In some cases, court officials at the highest levels have attempted to instruct duty counsel on issues touching on the lawyer's privileged relationship with his client. In other cases, the repeated insinuations of guilt, in violation of the defendant's presumption of innocence, were rather obvious. This was certainly my experience when I briefly served as court-appointed duty counsel in the Charles Taylor case at the Special Court for Sierra Leone in June 2007. That occurrence led to my resignation from that tribunal a few months later, after efforts to communicate the distinction between the two roles to the powers that be was ignored. Of course, by the time of my resignation, private defense counsel had been found for the defendant, and the case file had been properly transferred.

Yet, anecdotal evidence suggests that my experience in the Taylor case was not unique. Other defense lawyers have faced the same or similar type of dilemma in other international criminal courts. This experience indicates that, all things being equal, appointing a lawyer who 
is not staff as duty counsel may be relatively more expensive from a tribunal perspective but should be preferred in principle since, in contrast to private defense counsel, court staff attorneys are not typically as independent as are contracted private defense counsel. This is not to suggest that tribunal lawyers would compromise their clients' interests. Rather, it is to observe that despite the best possible advocacy and hard work of some of the best and most committed lawyers, they sometimes get trapped in a spiral that is not of their own making, reflecting a fundamental structural flaw in the institutional apparatus of international criminal justice. On the other hand, the benefits that will accrue from hiring private defense counsel to be duty counsel in any given case will depend on the tribunal and case under consideration, so assessments as to the right decision must be made on a situation-specific basis.

Court assigned counsel is imposed by order of the court, usually over the defendant's objections, and is given the responsibility to ensure the defense of the accused person. International tribunals usually assign attorneys to represent accused persons in circumstances where the chamber considers such assignment in the best interests of justice. Tribunals often make such a finding due to the defendant's substantial and persistent obstruction of the proceedings, which threatens the fair and proper administration of justice.

The role of a court-assigned lawyer must be distinguished from that of what we might for convenience call administratively appointed counsel. Administratively appointed counsel is normally selected and appointed to represent an indigent or partially indigent person by a tribunal administrator (usually the registrar or his delegate, the principal defender or equivalent), after full consultations with the defendant. Although the case law is often inconsistent in the terminology used, the distinction between court-assigned counsel and administratively appointed counsel is not only semantic, it is critical both for reasons of principle and practice. In principle, except perhaps when the defendant's previously chosen counsel is appointed by the court as standby counsel to continue to represent the accused, court-assigned counsel is the court's chosen lawyer representing the defendant in the proceedings rather than the defendant's choice legal representative.

In practice, depending on the reasons why counsel is being imposed, the lawyer forced upon an accused may not necessarily receive any instructions from the "client" or gain his cooperation on the presentation of the defense case. Whether the defendant instructs or refuses to instruct counsel obviously has serious implications for the type and effectiveness of the defense that the lawyer can mount to counter the prosecution's case. The appointment, therefore, usually raises ethical concerns for the attorney regarding the propriety of representing a 
defendant who might be unhappy or even prove to be uncooperative in respect of the defense.

Conversely, in the case of counsel administratively assigned by the registrar or the principal defender, the lawyer typically enjoys the cooperation of his client. An administratively assigned lawyer is usually selected from the list of counsel, taking into account the wishes of the accused. The attorney can therefore seek, receive, and act on instructions from the defendant on how best to challenge the prosecution's allegations. Consequently, because the accused participates in the selection of counsel, the accused is more likely to engage with the counsel to put forth a proper defense, including directing counsel to prospective witnesses.

The consequence of a lawyer's appointment to represent an accused by the court, instead of by administrative decision of the registrar, also affects who can terminate counsel. While usually permitted only during the pre-trial phase, lawyers administratively appointed to represent the accused can be replaced, for example, at the defendant's request simply by withdrawing counsel and replacing him with another. For practical reasons, the chances that counsel will be replaced at the accused's request decreases dramatically as the case progresses towards trial and becomes extremely difficult once trial has begun. The reason is that lawyers are generally expected to represent the defendants to the finality of the case, although this presumes that no total breakdown in the counsel-client relationship occurs along the way.

On the other hand, attorneys appointed to represent a defendant by order of the court can only be replaced by fiat of judicial decision. Furthermore, assuming that there is no serious breakdown in the lawyerclient relationship, the likelihood that a court will countenance an administrative change of appointed counsel diminishes dramatically once the trial has begun. A change in counsel is usually only allowed in the most exceptional circumstances when there is no serious threat of a delay to the case or disruption to the smooth continuation of the proceedings.

It follows that there is a type of interplay between the stage of the trial and the ability of administrators to fulfill the defendant's wish to replace his counsel. The closer to the hearing of evidence it is, the more likely that the chamber will have strong views as to whether it is truly necessary to replace counsel. In some courts, administrators therefore end up seeking informal approval from the judges before the power to administratively remove the lawyer is exercised. This type of informal check makes sense given the court's primary responsibility to adjudicate the case within a reasonable time and to provide the defendant with a fair trial, which includes, if the accused so wishes, the right to be represented by competent counsel. 
The third procedural device used by international criminal courts is amicus curiae, or "friend of the court." As specifically employed in international criminal trials, amicus curiae is a creative option that the tribunals have developed to ensure a particular (defense) perspective is presented during the trial or appeal phase of a case. The amicus counsel's duty is to assist the court in any manner counsel deems appropriate to ensure a fair trial and proper determination of the case before the court. For example, amicus counsel may make oral or written submissions on any procedural, evidentiary, or substantive issue that could have been properly raised in response to the prosecution case or bring to the chamber's attention any exculpatory or mitigating evidence in favor of the accused. ' The appointment of an amicus attorney usually takes place in situations where the defendant has resisted, or indicated that he will resist, the assignment or appointment of counsel to represent him because he prefers to represent himself personally.

Crucially, the amicus, whose main function is to assist the court in its task of rendering credible justice rather than to represent the defendant ${ }^{8}$ as such, may or may not receive any cooperation from the accused. The amicus operates independently of the accused, although he presents arguments intended to advance the accused person's position in the case. The chamber, having appointed counsel, also retains discretion to terminate the amicus curiae appointment. ${ }^{9}$ Termination can also occur where, for example, the accused complains that the conduct of such counsel shows that he is biased against the defendant or had already formulated conclusions as to guilt.

\section{B. Use of Counsel by the International Tribunals}

These three procedural devices involving various shades of counsel appointments have been used by the ICTY and other ad hoc tribunals such as the International Criminal Tribunal for Rwanda (ICTR), the Special Court for Sierra Leone (SCSL), the Special Tribunal for Lebanon (STL), and even in the nascent practice of the permanent International Criminal Court (ICC). They have been used in these tribunals both

6. Ballentine's Law Dictionary 69 (3d ed. 1969).

7. See Milošević, Order Inviting Designation of Amicus Curiae, supra note 2, ๆ 1 .

8. See Prosecutor v. Milošević, Case No. IT-02-54, Reasons for Decision on the Prosecution Motion Concerning Assignment of Counsel, I 3 (Int'l Crim. Trib. for the Former Yugoslavia Apr. 4, 2003) [hereinafter Milošević, Reasons for Decision on the Prosecution Motion Concerning Assignment of Counsel].

9. See Prosecutor v. Milošević, Case No. IT-02-54, Transcript of Record, at 11441, 11. 10-14 (Int'l Crim. Trib. for the Former Yugoslavia Oct. 10, 2002). 
individually, and in combination, with varying degrees of success. ${ }^{10}$ In making decisions regarding use of standby, amicus, or court appointed counsel to self-representing or disruptive defendants, international criminal courts are not simply flying blind. Statutory language that is drawn from universal and regional human rights instruments is commonly shared by nearly all of these tribunals, and helps to guide and shape or limit their rulings and approaches.

The International Covenant on Civil and Political Rights (ICCPR) states in Article 14(3)(d) that everyone shall be guaranteed, at a minimum, the right

[t]o be tried in his presence, and to defend himself in person or through legal assistance of his own choosing; to be informed, if he does not have legal assistance, of this right; and to have legal assistance assigned to him, in any case where the interests of justice so require, and without payment by him in any such case if he does not have sufficient means to pay for it. ${ }^{11}$

The ICTY in Article 21(4)(d) and the ICTR in Article 20(4)(d) adopt nearly the same language in their respective statutes, ${ }^{12}$ as does the SCSL in Article 17(4)(d). The European Convention on Human Rights (ECHR) similarly grants a criminal defendant the right "to defend himself in person or through legal assistance of his own choosing."13 The American Convention on Human Rights (ACHR) guarantees "the right of the accused to defend himself personally or to be assisted by legal counsel of his own choosing."14

Interestingly, the African Charter on Human and Peoples' Rights (ACHPR) diverges from the European and American conventions by granting a relatively broader right to a defense of which the role of counsel is only one component. Article 7(c) of the ACHPR provides each individual "the right to defense, including the right to be defended

10. The STL has not actually held a trial yet, but provisions of the rules of the Court reflect awareness of this issue. This observation is mentioned further below.

11. International Covenant on Civil and Political Rights, Dec. 16, 1996, 999 U.N.T.S. 171 [hereinafter ICCPR].

12. The ICTR statute reads "himself or herself" rather than only "himself." Statute of the International Criminal Tribunal for the Prosecution of Persons Responsible for Genocide and Other Serious Violations of International Humanitarian Law Committed in the Territory of Rwanda and Rwandan Citizens Responsible for Genocide and Other Such Violations Committed in the Territory of Neighbouring States, between 1 January 1994 and 31 December 1994, art. 20(4)(d), Nov. 8, 1994, available at http://www2.ohchr.org/english/law/itr.htm.

13. The European Convention on Human Rights and Human Freedoms art. 6, Nov. 4, 1950, 213 U.N.T.S. 222 [hereinafter ECHR].

14. Organization of American States, American Convention on Human Rights art. 8, Nov. 22, 1969, O.A.S.T.S. No. 36, 1144 U.N.T.S. 123 [hereinafter ACHR]. 
by counsel of his choice."15 Article 7(c) implies that the defendant, at least in principle, is also guaranteed the lawyer of his choice. That interpretation is obviously correct if the defendant pays for his lawyer. But this reading appears to be a much more expansive understanding of the scope of the right to counsel when public funds are being used if compared to the emerging jurisprudence of the international criminal tribunals that qualifies the right. Perhaps the African position is a welcome nuance to that jurisprudence in favor of the defendant, if indeed the right is actually given effect in practice.

Beyond the ACHPR, only two other ad hoc courts diverge from the nearly identical statutory provisions of the other tribunals. Although Article 67(d) of the Rome Statute of the International Criminal Court similarly enshrines the accused person's right "to conduct his defense in person or through legal assistance of the accused's choosing," it explicitly qualifies the enjoyment of that right. ${ }^{16}$ If the accused is present in court but "continues to disrupt the trial," the chamber "may remove the accused" after "other reasonable alternatives" have been exhausted. ${ }^{17}$ However, in such instances, the judges are obliged to provide alternate means for the accused "to observe the trial and instruct counsel from outside the courtroom."18 That said, recognizing the exceptional nature and potential negative impact of such a measure on the fairness and ultimate outcome of the proceedings, Article 63(2) provides that barring defendants from court and ordering alternative forms of participation is strictly limited to the duration necessary for the trial's return to normalcy. ${ }^{19}$

Similarly, while Article 16(4)(d) of the Statute of the STL grants defendants the right to "be tried in his or her presence, and to defend himself or herself in person or through legal assistance of his or her own choosing," the STL's Rules of Evidence and Procedure state that "[t]he Pre-Trial Judge or a Chamber may impose counsel present or otherwise assist the accused in accordance with international criminal law and international human rights where this is deemed necessary in the interests of justice and to ensure a fair and expeditious trial." ${ }^{20}$ This final

15. African [Banjul] Charter on Human and Peoples' Rights, June 27, 1981, OAU Doc. CAB/LEG/67/3 rev. 5, 21 I.L.M. 58 (1982) (entered into force Oct. 21, 1986).

16. The fair trial rights of the accused are set forth in Article 67, whereas Article 63 discusses trial presence. See Rome Statute of the International Criminal Court arts. 63, 67 , July 17, 1998, 2187 U.N.T.S. 3 (entered into force on July 1, 2002) [hereinafter Rome Statute].

17. Id. art. 63.

18. Id.

19. Id.

20. See STL R. P. \& Evid. 59F, STL/BD/2009/01/Rev. 3 (Mar. 20, 2009) (as amended) [hereinafter STL RPE] (emphasis added). 
provision appears to be the key difference between the rules of the STL and the other ad hoc penal tribunals. ${ }^{21}$ Essentially, the STL introduces a second qualifying phrase to the right to defend oneself, thereby granting the judges greater leeway to restrict the enjoyment of that right. Under the Rome Statute scheme discussed above, the chamber may limit the exercise of this broad right based on the authority explicitly conferred by the primary statute rather than the subordinate rules of procedure and evidence as envisaged under the STL.

Nevertheless, the language contained in the ICTY and ICTR Statutes seem simple and clear enough. It is, after all, essentially the same language used in at least three international conventions defining the human rights of accused persons. ${ }^{22}$ Unfortunately, international criminal courts have not found the application of this language easy or satisfying. The problems the pioneering ICTY and ICTR have experienced in dealing with disruptive and self-representing defendants is at least partially responsible for the change in statutory or regulatory language employed by the ICC and other tribunals such as the STL. ${ }^{23}$

\section{Issues that Arise for Self-Representing Defendants and Counsel in International Tribunals}

There are many aspects to the question of how to appropriately handle these types of situations, most of which have been faced by an international court at least once. Issues that have arisen include the following: handling requests to appear pro se at various stages of trial, ${ }^{24}$

21. The Rules of Procedure and Evidence of the International Criminal Tribunal for the Former Yugoslavia state in Rule 45ter that " $[t]$ he Trial Chamber may, if it decides that it is in the interests of justice, instruct the Registrar to assign a counsel to represent the interests of the accused." ICTY R. P. \& EVID. 45ter (B), U.N. DoC. IT/32/Rev. 17 (Dec. 7, 1999) (as amended) [hereinafter ICTY RPE]. Rule 45 quater of the International Criminal Tribunal for Rwanda Rules of Procedure and Evidence is identical to the ICTY rule. See ICTR R. P. \& EVID. 45 quater (Oct. 1, 2009) (as amended) [hereinafter ICTR RPE]. The Special Court for Sierra Leone Rules of Procedure and Evidence states in Rule 45 (B)(ii) that the defense office shall provide "legal assistance as ordered by the Special Court in accordance with Rule 61 , if the accused does not have sufficient means to pay for it, as the interests of justice may so require." SCSL R. P. \& EVID. 45(B)(ii) (Apr. 12, 2002) (as amended) [hereinafter SCSL RPE].

22. See ICCPR, supra note 11; ECHR, supra note 13; ACHR, supra note 14.

23. See generally Michael Scharf, Chaos in the Courtroom: Controlling Disruptive Defendants and Contumacious Counsel in War Crimes Tribunals, 39 CASE W. RES. J. INT'L L. 155 (2006-07); Mark Ellis, The Saddam Trial: Challenges to Meeting International Standards of Fairness with Regard to the Defense, 39 CASE W. RES. J. INT'L L. $171(2006-07)$.

24. See generally Prosecutor v. Krajišnik, Case No. IT-00-39-T, Decision on Admission of Documents Tendered by Mr. Krajišnik (Int'l Crim. Trib. for the Former Yugoslavia Aug. 31, 2005); Prosecutor v. Norman, Case No. SCSL-04-14-T-125, Decision on the Application of Samuel Hinga Norman for Self-Representation Under 
determining the extent of responsibilities and powers of standby and amicus counsel, ${ }^{25}$ allowing standby or amicus counsel to take over the case when a defendant is removed from court or absent, ${ }^{26}$ pre- and midtrial requests for a change to either standby or appointed counsel, ${ }^{27}$ disruption caused by retained counsel, ${ }^{28}$ the extent of public legal resources and advice that should be given to self-represented defendants, ${ }^{29}$ and other related issues.

In making decisions regarding the scope of counsel's role in a trial, international courts must balance many different, and sometimes conflicting, rights. These include the right of the defendant to a fair trial, the right to an expeditious trial, the rights of all those participating in the trial, including the accused and the victims, and the seemingly conflicting absolute right to counsel and equally fundamental right to refuse the assistance of counsel. ${ }^{30}$ In addition, all of these specific rights are viewed within the context of the broad and amorphous concept of "interests of justice" as indicated by the statutory provisions above. ${ }^{31}$

Article 17(4)(d) of the Statute of the Special Court (June 8, 2004) [hereinafter Norman, Decision on the Application of Samuel Hinga Norman for Self-Representation]; Prosecutor v. Gbao, Case No. SCSL-04-15-T-285, Decision on Appeal against Decision on Withdrawal of Counsel (Nov. 23, 2004).

25. See generally Prosecutor v. Karadžić, Case No. IT-95-5/18-AR73.6, Decision on Radovan Karadžićs Appeal from Decision on Motion to Vacate Appointment of Richard Harvey (Int'l Crim. Trib. for the Former Yugoslavia Feb. 12, 2010); Prosecutor v. Milošević, Case No. IT-02-54-AR73.7, Decision on Interlocutory Appeal of the Trial Chamber's Decision on the Assignment of Defense Counsel (Int'l Crim. Trib. for the Former Yugoslavia Nov. 1, 2004) [hereinafter Milošević, Decision on Interlocutory Appeal of the Trial Chamber's Decision on the Assignment of Defense Counsel]; Prosecutor v. Šešelj, Case No. IT-03-67-PT, Order Concerning Appointment of Standby Counsel and Delayed Commencement of Trial (Int'l Crim. Trib. for the Former Yugoslavia Oct. 25, 2006).

26. See generally Prosecutor v. Karadžić, Case No. IT-95-5/18-T, Decision on Appointment of Counsel and Order on Further Trial Proceedings (Int'l Crim. Trib. for the Former Yugoslavia Nov. 5, 2009) [hereinafter Karadžić, Decision on Appointment of Counsel and Order on Further Trial Proceedings].

27. See generally Prosecutor v. Nyiramasuhuko, Case No. ICTR-97-21-T, Decision on Ntahboli's Motion for Withdrawal of Counsel (June 22, 2001).

28. See generally Prosecutor v. Charles Taylor, Case No. SCSL-2003-01-T, Prosecution Opening Statement, Transcript of Record (June 4, 2007) [hereinafter Taylor, Transcript of Record]; Scharf, supra note 23, at 164.

29. See Ššelj, Decision on Prosecution's Motion for Order Appointing Counsel to Assist Vojislav Šešelj with His Defence, supra note 4, ๆף 28-30; Prosecutor v. Janković, Case No. IT-96-23/2-PT, Decision Following Registrar's Notification of Radovan Stanković's Request for Self-Representation, \24 (Int'l Crim. Trib. for the Former Yugoslavia Aug. 19, 2005).

30. See Nina Jørgenson, The Problem of Self-Representation at International Criminal Tribunals: Striking a Balance Between Fairness and Effectiveness, 4 J. INT'L CRIM. Just. 64, 69 (2006).

31. Göran Sluiter, Fairness and the Interests of Justice: Illusive Concepts in the Milošević Case, 3 J. InT’L CRIM. Just. 9, 12 (2005). 
As several appellate courts in some national jurisdictions have emphasized, in these types of cases, the court must walk a "thin line ... between improperly allowing a defendant to proceed pro se, thereby violating the right to counsel," and improperly requiring the defendant to proceed with counsel, thereby violating his right to defend himself. ${ }^{32}$ In regards to the role of standby counsel and/or amicus curiae, this line becomes difficult to tread because standby counsel could violate the defendant's rights by acting either too little or too much during a trial. Defendants in the United States, for example, have appealed trials in which they appeared pro se by claiming both that standby counsel interfered too much (violating their right to defend themselves) ${ }^{33}$ and that a court's use of standby or appointed counsel was insufficient (violating their right to the protections of counsel). ${ }^{34}$

Considering the frequency with which the landmark U.S. Supreme Court decision in Faretta $v$. California, ${ }^{35}$ (establishing the right to selfrepresentation in the United States), is cited by every international tribunal, ${ }^{36}$ these same problems often arise in international settings. The bad news for international criminal justice is that all of these competing rights and interests make it nearly impossible to create hard and fast rules for the role of counsel at any particular trial. ${ }^{37}$ The good news is that balancing these interests allows international courts to learn from the past and tweak their assessment of these rights, thereby redefining the appropriate role of counsel in factually and legally complex international criminal trials. As they tend to construe the text of the fair trial provisions contained in their instruments in a manner that accords with the letter but also the spirit of the rights enshrined by international human

32. United States v. Frazier-El, 204 F.3d 553, 559 (4th Cir. 2000) (quoting Fields v. Murray, 49 F.3d 1024, 1029 (4th Cir. 1995) (en banc) (quoting Cross v. United States, 893 F.2d 1287, 1290 (11 th Cir.1990)).

33. See generally McKaskle v. Wiggins, 465 U.S. 168 (1984).

34. Clark v. Perez, 510 F.3d 382 (2d Cir. 2008).

35. Faretta v. California, 422 U.S. 806 (1975).

36. See, e.g., Prosecutor v. Šešelj, Case No. IT-03-67-PT, Decision on Assignment of Counsel, If 15 (Int'l Crim. Trib. for the Former Yugoslavia Aug. 21, 2006) [hereinafter Šešelj, Decision on Assignment of Counsel]; Milošević, Decision on Interlocutory Appeal of the Trial Chamber's Decision on the Assignment of Defense Counsel, supra note 25, I11; Barayagwiza, Decision on Defense Counsel Motion to Withdraw, supra note 4, (Gunawardana, J., concurring); Prosecutor v. Gbao, Case No. SCSL 2004-15-T, Prosecution's Submissions to Gbao's Appeal from Decision on Withdraw of Counsel of 6 July 2004, ๆ 25 (Sept. 22, 2004), available at http://www.sc-sl.org/scsl/Public/SCSL04-15-PT-RUF/SCSL-04-15-T-248.pdf.

37. In fact, the Rules of Procedure and Evidence at the ICTY have been amended over 40 times since 1993 to account for shifts in the Court's attempt to balance fairness and expediency. See Fausto Pocar, Int'l Ass'n of Procedural L., Common and Civil Law Traditions in the ICTY Criminal Procedure: Does Oil Blend with WATER? 3-4 (2009). 
rights, these relatively new tribunals have breathed life in otherwise vague human rights provisions. These international tribunals have done so in light of problems and experiences garnered from concrete criminal trials at the national level.

Courts of international law, however, also have more leeway than most national jurisdictions recognizing the right to self-representation. The procedures of international criminal law are usually a blend of two major Western legal traditions: (1) the common law/Anglo-American law and (2) civil law or Continental/Romano-Germanic systems. ${ }^{38}$ While the right to represent oneself is almost unanimously recognized by countries operating with a predominantly common law legal system, countries with a mostly civil law orientation do not always recognize such a right. ${ }^{39}$ Various reasons exist for this distinction; for this article's purposes, however, the most relevant reason is that many civilian systems mandatorily assign defense counsel in criminal cases because it is deemed to be in the best interests of justice for the accused to be assisted by counsel. ${ }^{40}$

Not all civil law traditions structure the mandatory assignment of a lawyer in criminal cases the same way. ${ }^{41}$ For some civil law countries, like Italy, counsel must always be present; whereas, for other countries such as Germany, this requirement of counsel is confined only to cases where the accused is charged with serious crimes. ${ }^{42}$ Other civil law countries occupy an intermediate twilight zone between these two extremes. For instance, in the practice of criminal courts in France and Belgium, ${ }^{43}$ counsel will be imposed only if the accused does not initially choose counsel. This discrepancy in the general attitudes of "inquisitorial" civil law systems, compared to "adversarial" common law

38. See Michael Scharf \& Christopher Rassi, Do Former Leaders Have an International Right to Self-Representation in War Crimes Trials?, 20 OHIо ST. J. ON DisP. RESOL. 3, 15 (2005). See generally Gideon Boas, Self-Representation before the ICTY: A Case for Reform, 9 J. INT'L CRIM. JUST. 53 (2011).

39. See Šešelj, Decision on Assignment of Counsel, supra note 36, ๆ 20.

40. See Prosecutor v. Milošević, Case No. IT-02-54-T, Reasons for Decision on Assignment of Defence Counsel, If 49 (Int'l Crim. Trib. for the Former Yugoslavia Sept. 22, 2004) [hereinafter Milošević, Reasons for Decision on Assignment of Defence Counsel].

41. Šešelj, Decision on Assignment of Counsel, supra note 36, $\llbracket 21 ;$ Šešelj, Decision on Prosecution's Motion for Order Appointing Counsel to Assist Vojislav Šešelj with His Defence, supra note 4, $\uparrow 16$.

42. See Strahprozessordnung [StPO] [Code of Criminal Procedure], Apr. 7, 1987, BUNDESGESETZBLATT [BGBL] 2646, as amended, $\S 140$, para. 1, sentence 2 (Ger.).

43. See Code de Procédure Pénale [C. Pr. Pén.] arts. 274, 317 (Fr.); Code D'INSTRUCTION CRIMINELLE [C.I.CR.] art. 294 (Belg.). 
systems, requires a broad, big-picture balancing. ${ }^{44}$ Thus, while international criminal procedure remains a work in progress, the international penal tribunal must seek to reconcile underlying philosophical differences between the national legal principles that form the basis of the procedural decisions and rules defining the role of the parties, especially the accused and his counsel in a criminal trial. ${ }^{45}$

To understand how the role of counsel is defined at the international level thus requires an understanding of two intertwined balancing processes. The first is the balancing of the uneven blend of common and civil law principles that resulted in the emergence of a mixed system of international criminal procedure. This mixed procedural system provides a generally credible institutional apparatus within which to pursue the prosecution of the types of heinous and large-scale crimes when available national level legal remedies are either unavailable or inadequate. ${ }^{46}$ The second is the balancing of aforementioned considerations raised by the largely adversarial criminal trials likely taking place a considerable distance from the scene of the alleged crimes on a very public and visible stage involving high profile and usually astute defendants.

By first recognizing and considering each of these complex balancing processes and the situations in which they arise at the international level, I hope to (re)define the lines for the appointment of counsel. I similarly hope to advance understanding of the best practices available to international penal courts with respect to standby, amicus, or assigned counsel in specific cases where a defendant chooses to defend himself personally or is disruptive.

\section{COMMON LAW AND CiVIL LAW PeRSPECTIVES ON THE Right to SELF-REPRESENTATION AND APPOINTMENT OF COUNSEL}

\section{A. Differing Theories about the Purpose of Criminal Trials}

The use of counsel in the common and civil law systems diverges rather noticeably. This divergence has been attributed to the differing theories of trial used in each system. In the civil law system, where the judge acts in an investigatory role to find his own route to the truth,

44. For a discussion of the different types of truths sought, see SALVATORE ZAPPALÀ, Human RightS IN INTERNATIONAL CRIMINAL PROCEEDINGS 16 (2003).

45. See Milošević, Reasons for Decision on Assignment of Defence Counsel, supra note 40 , ๆ 50 .

46. For a discussion of the benefits from mixing common and civil procedural norms into a unique international system, see generally POCAR, supra note 37. 
counsel is not an essential guarantor of a defendant's rights. ${ }^{47}$ By contrast, in the common law system, where the judge is deemed a neutral arbiter or referee between two supposedly equal adversaries, counsel bears primary responsibility for protecting the rights of his accused client by exploring every recognized avenue to ensure that the accused receives due process. ${ }^{48}$ It may therefore seem odd that the right to forgo the assistance of counsel and represent oneself is a normal feature of common law systems where counsel's role is a considerably more important facet of a fair trial.

Civil law systems generally do not recognize a defendant's right to conduct his own defense, despite, or perhaps because, defense counsel plays a much less significant role in determining the outcome of the trial. In addition to the routine and mandatory assignment of counsel in serious criminal cases, another explanation seems to be that, in the civilian system, judges are simply applying comprehensive statutory provisions. There is little room for interpretation about what the law is or what the law should be. In contrast, the common law tradition is typically assumed to rest upon judges interpreting community norms and using their discretion to apply general principles found in previous precedent. Because there is a greater likelihood of policy considerations and discussion of how the law should be read in a common law court, especially due to the jury's role in adjudicating felony level offenses, there is a greater emphasis placed upon defendant autonomy. The defendant could theoretically persuade the judge and jury to see things a particular way.

Furthermore, in common law systems, counsel-primarily through the selection of witnesses and cross-examination of the other side's witnesses-effectively contribute to shaping the facts and outcome of the trial as ultimately determined by the jury. At the same time, with his professional legal training, the competent defense lawyer is in most cases best able to advise his client who, essentially, may exercise his legal right to hold the prosecution to proof of the charges beyond a reasonable doubt by not introducing any evidence in return. In the civil law tradition, there is a much smaller persuasive aspect to a criminal trial, and the need to preserve defendant autonomy is minimized given the seemingly mechanical application of law to fact that is emphasized. Because international courts have thus far adopted a system that is essentially adversarial rather than inquisitorial in nature, the common law emphasis

47. See Rosemary Byrne, The New Public International Lawyer and the Hidden Art of International Criminal Trial Practice, 25 CONN. J. INT'L L. 243, 249 (2010).

48. See id. at 261. 
on individual autonomy has largely prevailed in international criminal trials focused on ensuring fair trials - at least during the early cases. ${ }^{49}$

In civil law systems, the presence of counsel is not necessarily seen as divesting the defendant of his right to speak in court on his own behalf due to the assistance of a lawyer. Conversely, common law courts tend to take the view that the presence of counsel essentially overrides the rights of the individual to directly participate so long as his lawyer, the expert so to speak, is present and representing him in court. Furthermore, the extremely technical rules governing the admissibility of evidence, a significant characteristic of common law trials that have been largely abandoned in international criminal trials, may also dampen the idea of direct defendant participation in procedurally complex trials.

\section{B. Principles Shaping the Use of Counsel in Common Law and Civil Law Systems}

It is useful to consider the principles shaping the common law rules on use of standby and amicus counsel before assessing how they compare to the "interests of justice" principles frequently invoked in international criminal trials.

In $R$. v. Woodward, ${ }^{50}$ an early case addressing this issue in the United Kingdom, the English Court of Criminal Appeal held that a defendant had a right to present his own defense to a jury, and the court could not force counsel upon him against his will. This brief opinion highlights two key considerations. First is the explicit reference to the jury, to whom the defense case will be presented. Second is the defendant's will, which the court may not violate by appointing counsel.

These same two considerations reappeared in the U.S. Supreme Court 40 years later in McKaskle v. Wiggins, ${ }^{51}$ in which the Court established the limits upon standby counsel action during a trial. The McKaskle Court indicated that standby counsel could autonomously take whatever action he deemed appropriate, provided that two important limitations are respected. ${ }^{52}$ First, the accused must maintain actual control over the case presented, and, second, the participation of standby counsel cannot taint the jury's perception that the accused is conducting or controlling his own defense. ${ }^{53}$

49. See Milošević, Order Inviting Designation of Amicus Curiae, supra note 2.

50. R. v. Woodward, [1944] K.B. 118, 29 Crim. App. 159.

51. McKaskle v. Wiggins, 465 U.S. 168 (1984).

52. Id.

53. Id. 
In the leading Faretta case, ${ }^{54}$ the U.S. Supreme Court recognized the importance of individual autonomy. The Court reasoned that, since the individual alone would bear the penalties and consequences for the effectiveness of the defense, the decision on how to proceed is rightfully placed in his hands. ${ }^{55}$ The Court also reasoned that a defendant is presumed innocent and, thus, the right to autonomous control over his defense cannot be stripped away; to find otherwise would render the defendant "imprisoned in his privileges." 56

In R. v. Swain, ${ }^{57}$ the Supreme Court of Canada similarly identified respect for individual autonomy as the basis for its conclusion that an adversarial system requires the court to allow the defendant to control his own defense. The respect for individual autonomy recognized by the British, American, and Canadian courts is a frequently cited basis for common law decisions restricting the role of counsel at a defendant's request. The Ontario Court of Appeals, however, provided perhaps the most colorful and illuminating statement on the nature of the common law system in Phillips v. Ford Motor Company: ${ }^{58}$

A trial is not intended to be a scientific exploration with the presiding judge assuming the role of a research director; it is a forum established for the purpose of providing justice for the litigants. ${ }^{59}$

Although this statement shows a common law judge's rejection of an investigative role, a civil law judge would be much more likely to embrace the idea that the trial is a scientific exploration for the truth. This quote underscores the most basic distinction between the two different legal traditions. In the common law system, the goal of a criminal trial is to dispense justice, although that may be variedly defined; whereas, in the civil law system, the goal of such proceedings is to establish the truth. ${ }^{60}$

This fundamental philosophical difference becomes clearer following an examination of civil law systems and the codes governing them. As a general rule, there is much less importance placed on the notion of a defendant's autonomy in the civil law tradition. In comparing France to the United States, for example, there are generally

54. Faretta v. California, 422 U.S. 806 (1975).

55. See id. at 834 .

56. Id.

57. R. v. Swain, [1991] S.C.R. 933 (Can.).

58. Phillips v. Ford Motor Co. (1971), 18 D.L.R. 3d 641 (Can. Ont. C.A.).

59. Id.

60. See Byrne, supra note 47 , at 255 . 
greater limitations placed upon plea-bargaining in France. ${ }^{61}$ The pre-trial investigatory process is not nearly as restricted by defendant's rights, and evidence is less frequently excluded from trial. ${ }^{62}$ Still, the emphasis on an efficient finding of truth in France is not limited to pre-trial procedure.

In France, written briefs submitted to the bench are of much greater importance than in the United States. ${ }^{63}$ This is reportedly because, in civilian systems, the trial does not play the central role in criminal justice that it does in the common law. ${ }^{64}$ Due to the extensive pre-trial judicial investigation and the emphasis on written submissions to the court, the trial does not play nearly as large a determinative function in deciding the outcome of the case. ${ }^{65}$ Rather than being a forum within which to hear and evaluate all the evidence, the trial is merely another means by which the judge obtains further evidence that has not already been presented. This doctrinal attitude about the place of trials in a larger process demonstrates the court-centric rather than party-centric emphasis the civil law system employs in determining the outcome of a particular criminal case.

Yet, as important as it is, this difference should not be overstated. In fact, even the common law acknowledges and tries to address the tensions that lead the civilian system to its more pragmatic approach. For instance, as Chief Justice Burger observed in dissent in Faretta, the trial judge in a common law court is not simply an "automaton" to ensure adherence to technical evidence rules but also someone responsible for ensuring that justice, in its broadest sense, is achieved in every criminal trial so that public confidence in the system is not undermined ${ }^{66}$ Thus, the dissenter warned that the criminal justice system should not be perverted and transformed into an "instrument of self-destruction" by essentially providing a rope for frustrated or foolish defendants to hang themselves in society's full view, or worse, with its complicity or acquiescence. ${ }^{67}$

61. See Edward A. Tomlinson, Non-Adversarial Justice: The French Experience, 42 MD. L. REv. 131, 161 (1983); see also PoCAR, supra note 37, at 3 (noting that the absence of plea-bargaining is a characteristic of most civil law systems, and its absence was one of the aspects of the civil law that was adopted by the ICTY from the beginning).

62. See Tomlinson, supra note 61 , at 161.

63. Jean-FrançoIs Poudret \& SÉbastien Besson, Comparative Law of INTERNATIONAL ARBITRATION 559 (2d ed. 2007).

64. See generally Tomlinson, supra note 61 .

65. See POCAR, supra note 37, at 7 (asserting that pre-trial written submissions are starting to play a larger role in international trials but still do not reach the same level of thoroughness as a civil law dossier).

66. Faretta v. California, 422 U.S. 806, 839 (1975) (Burger, C.J., dissenting).

67. Id. at 840 (Burger, C.J., dissenting). 
The decreased focus on defendant autonomy and increased focus on the independent inquiry of the court is exemplified by the civil law rules regarding the assignment of counsel. Consider the German Code of Criminal Procedure, which broadly defines when the assignment of counsel is mandatory and further stipulates:

In other cases the presiding judge shall appoint defense counsel upon application or ex officio if the assistance of defense counsel appears necessary because of the seriousness of the offence, or because of the difficult factual or legal situation, or if it is evident that the accused cannot defend himself, particularly where an attorney has been assigned to the aggrieved person pursuant to Sections 397a and 406g subsections (3) and (4). ${ }^{68}$

This provision grants the judge a great deal of discretion in assigning defense counsel to the accused, even in situations where counsel is not already mandatory. ${ }^{69}$ The judge's authority to impose counsel upon a criminal defendant also seems to stem from the civil law's focus on truth finding over resolution seeking. The resolutionseeking court must preserve respect for individual autonomy in order to guarantee confidence from the parties involved that both sides were given a fair chance to present their positions and that the winner was more convincing. The truth-seeking court is less concerned with the perceptions of the parties involved in any particular case and more concerned with the general aim for accurate decisions in most instances.

The greater discretion of judges to impose defense counsel against the wishes of an accused in civilian systems can also be attributed to the more active role the judge takes during the course of a criminal trial. Because the judge is personally questioning witnesses and making decisions about the direction of the trial, appointing counsel has significant benefits to the judge in executing his responsibilities. In a common law system, it is easier for the judge to exercise his role as a "neutral" arbiter when dealing with counsel rather than the defendant directly. The increased power the judge wields over counsel through sanctions, penalties and fines, has less impact upon the accused. ${ }^{70}$ In the civil law system, however, the assignment of counsel is more than just convenient for judges. Because the judge must determine what happened, requiring counsel from both sides to assist allows the judge greater certainty about both the facts of the case and the decision the court will reach. It seems to follow that the underlying goals and the

68. Strahprozessordnung [StPO] [Code of Criminal Procedure], Apr. 7, 1987, BUNDESGESETZBLATT [BGBL] 2646, as amended, § 140, para. 2 (Ger.).

69. See, e.g., Ššelj, Decision on Assignment of Counsel, supra note 36, ๆ 21.

70. See Scharf, supra note 23, at 161. 
structure of each criminal justice system dictates the divergences in appointing counsel between the common and civil law traditions.

In any case, given the not entirely compatible goals of truth and justice, it is up to the international criminal law to shape a shared system of criminal procedure and professional roles that reflects the values of both the civil and common law. ${ }^{71}$ Of course, both truth and justice play an extremely important role in international criminal law given the reasons behind its implementation. International criminal law, although rather too ambitiously, was initially couched as a way to "end... impunity" for some of the worst crimes otherwise not prosecuted in national courts. ${ }^{72}$ As if that grand objective is not enough, the international community also envisaged that the creation of these courts will also help establish a historical record and thereby foster national healing and reconciliation in countries torn apart by age-old ethnic animosities and violent crimes committed on a vast scale. ${ }^{73}$

To achieve the goals of ending impunity and fostering national healing, both truth and justice are vital factors. Revealing the facts about the crimes that the guilty are charged with committing is vital to allowing countries to learn and perhaps even, with the passage of time, to move past the atrocities. In this sense, the civil law focus on finding and proclaiming absolute truth with regard to an individual's actions is seemingly more desirable as a way to facilitate a country's acceptance of the legitimacy of international proceedings. In fact, this pragmatic posture seems to make sense since international criminal law essentially treads on the toes of states in an area that was classically deemed their exclusive preserve: the exercise of criminal jurisdiction that is both an attribute and a function of sovereignty.

Alternatively, a focus on justice bears just as much importance for the goals of international justice and the perceptions surrounding it. It is important that international tribunals not lose their legitimacy in making decisions by being perceived as "western" or "winner's" justice only. To avoid this perception, fairness to the defendant and respect for the defendant's autonomy during trial is essential. It therefore becomes clear that, for an international penal court to have even the hope that it will accomplish its tall primary and secondary goals, the procedure of trial must maintain a focus on capturing both truth and justice. In order to do

71. Byrne, supra note 47.

72. Rome Statute, supra note $16, \mathrm{pmbl}$.

73. See S.C. Res. 955, 1, U.N. DoC. S/RES/955 (Nov. 8, 1994). 
that, a blending and melding of common and civil law concepts and methods in concrete cases appears paramount. ${ }^{74}$

\section{APPLICATION OF COMMON LAW AND CIVIL LAW APPROACHES IN THE INTERNATIONAL CRIMINAL TRIBUNALS}

International courts in any given trial can face numerous potential decisions regarding the role of counsel. These decisions include questions about the amount of time or resources a defendant will have to prepare for trial or how much funding a defendant will be allowed for hiring a defense team. However, the most frequent and most significant decisions that face international criminal tribunals tend to center around three major questions:

(1) Will or should the court appoint counsel for the defendant, or allow him to conduct his own defense?

(2) Will or should the court appoint standby counsel and/or amicus curiae, and, if so, what role should they be given?

(3) What is the appropriate response in emergency situations when the defendant (and/or his counsel) is either absent or so disruptive that they need to be removed from court?

Both the growing body of international criminal law and numerous national jurisdictions have already confronted these questions many times over. Each question can be analyzed at the international level by considering the balancing of interests by the court, as well as the goals and procedures employed by common and civil law systems at the national level.

\section{A. Should the Court Appoint Counsel for the Defendant or Allow Him to Represent Himself?}

In considering whether the court should permit the defendant to represent himself or to appoint counsel to act on the accused's behalf, even over his objection if necessary, the Milošević trial provides an excellent case study, although it set a precedent on self-representation

74. Although, on the other hand, unlike customary law or Islamic legal traditions, the more prevalent common and civil law systems are typically associated with the West. For a case-specific discussion of this idea, see, e.g., Linda E. Carter, Justice and Reconciliation on Trial: The Gacaca Proceedings in Rwanda, 14 NEW ENG. J. INT'L \& COMP. L. 41 (2007). 
that has come under scathing criticism over time. ${ }^{75}$ In allowing Milošević's initial request to represent himself, the judges, as discussed at the outset of this article, seemed primarily concerned with respecting the defendant's rights and guaranteeing that there was no question that the tribunal was granting him a fair trial. ${ }^{76}$ The Trial Chamber, in an August 30, 2001 ruling, reasoned that Milošević's assertion of the right was both timely and unequivocal and that Article 21(4)(d) guaranteed his right to conduct his own defense. ${ }^{77}$ The judges then appointed three amicus curiae to ensure that Milošević's right to defend himself was not disturbed by the court.

Still, the appointment of amici was not the end of the court's decision regarding the role of counsel in that case. The judges had to confront the question about what should be done about Milošević's right to self-representation on at least three subsequent occasions. The prosecutor, who had urged the court to appoint defense counsel over Milošević's wishes in their initial ruling, waited just over a year to again urge the Trial Chamber to take action. ${ }^{78}$

In an oral ruling on December 18, 2002, the Trial Chamber again rejected the prosecutor's request but promised to keep the matter under review. ${ }^{79}$ In September 2003, the prosecution sought a hearing to address how the court should proceed in light of the disruptions to the trial posed by Milošević's poor health. ${ }^{80}$ The judges, faced with this issue for the third time, issued a ruling reducing the number of days the court would sit to three per week, giving him time to rest and recover in between days in court. ${ }^{81}$ Finally, after further disruptions, numerous submissions from the prosecutor and amici counsel, and health evaluations by three different physicians, the chamber decided in an oral ruling on September 2, 2004, that Milošević's health required them to appoint defense counsel so that the trial could proceed. ${ }^{82}$

At each of these four points of the trial, the Trial Chamber sought to balance a number of considerations in its determination of whether to assign counsel for Milošević. In its explanation of the reasons for the

75. See Boas, supra note 38 , at 55 (criticizing the ICTY approach to selfrepresentation, first developed in Milošević, as "a poor legal ruling" that has led to "less than satisfactory" and "farcical" results in later case law).

76. See Milošević, Reasons for Decision on the Prosecution Motion Concerning Assignment of Counsel, supra note 8, $\{3$.

77. See id.

78. See Milošević, Reasons for Decision on Assignment of Defence Counsel, supra note 40 , 7 .

79. Id. ๆ 8.

80. Id. $\uparrow 9$.

81. Id. $\| 10$.

82. Id. ๆ 1 . 
oral ruling on December 18,2002 , the court provided two primary justifications for refusing to impose counsel on Milošević. The judges felt that, since the ICTY was essentially operating on the adversarial model for its trials, it was necessarily required to follow accepted common law rules regarding the use of counsel at trial. ${ }^{83}$ The judges cited the U.S. Supreme Court decision in Faretta and reasoned that depriving the defendant of his right to represent himself would effectively be depriving him of the right to put forth his own defense. ${ }^{84}$ The chamber, in reaching this conclusion, drew parallels between the American common law system and the rules established by the ICCPR and ECHR, as well as the statute for the ICTY itself. ${ }^{85}$ The court thus determined that, as a matter of principle, the ICTY rules established an adversarial system to preserve the rights of the defendant and to ensure a just trial occurred. ${ }^{86}$ Interestingly, likely unwittingly, the court largely ignored case law from the civil law system that might have been incorporated into their reasoning to reach a more reasonable and balanced result as between the rights of the accused and the tribunal's right to render credible justice.

The Trial Chamber attempted to be pragmatic in their second explanation for their ruling. They determined that, if they imposed counsel on Milošević and then he refused to cooperate, they would either have to cut the defendant out of the trial altogether or relegate assigned counsel to a role no greater than that of the amici counsel ${ }^{87}$ The judges noted that they already had three lawyers assisting the court and did not want to raise fairness concerns by denying Miloševic the right to participate in his trial. ${ }^{88}$ One could legitimately question whether the chamber was too deferential toward the defendant considering that other interests, such as those of the victims and justice, were also at stake. But, in civil law systems, the accused is still typically allowed to participate in the trial by intervening to cross-examine witnesses after counsel and the judge are finished with their questions. ${ }^{89}$ The irony, of course, is that civilian systems would have imposed counsel at this stage. It follows that, instead of capitulating to the defendant's threat that he will not participate if counsel is imposed upon him, the chamber could have

83. See Milošević, Reasons for Decision on Assignment of Defence Counsel, supra note 40 , \ 45 .

84. Id.

85. See id. 1 (ศ $22-32$.

86. Id.

87. Id. $\lceil 3$.

88. Id. ๆๆ 3-4.

89. Wolfgang Schomburg, The Role of the International Criminal Tribunals in Promoting Respect for Fair Trial Rights, 8 Nw. U. J. INT'L HUM. RTs. 1, 21 (2009). 
offered him a limited right to speak in court, on a case-by-case basis, with the leave of the presiding judge. This alternative could have been conditioned on the undertaking that he would comport himself with the court's orders. The ICTY has subsequently used this approach in some later cases.

In any event, the balancing of interests had changed for the court by September 2004. In that decision, the Trial Chamber highlighted its fundamental duty to ensure a fair and expeditious trial. The court determined that allowing Milošević to proceed without counsel jeopardized the completion of the trial in a reasonable time, if at all. ${ }^{90}$ After granting concession after concession so that Milošević could exercise a right the court considered fundamental to the adversarial process, the judges finally reached the conclusion that the overall faimess of the trial process needed to take precedence over guarantees of fairness to the defendant personally. ${ }^{91}$

Perhaps as a signal of the shift from an absolute to a qualified right of self-representation, the Milošević Trial Chamber's September 2004 decision did not cite U.S. case law and, instead, the court supported its ruling with citations to the Barayagwiza case decided by the ICTR and the Norman case from the SCSL. ${ }^{92}$ Those international decisions gave less latitude to the defendant, much like continental systems do, favoring instead a focus on the big picture desire to dispense justice. This shift in Milošević from common law to civil law type attitudes can be explained in part by the change in composition of the bench because Presiding Judge Richard May resigned for health reasons. Nevertheless, this swing of the pendulum and adoption of case law from other tribunals helped the judges justify their decision to curtail Milošević's right to represent himself in the greater interests of justice.

In Barayagwiza, the ICTR did not have to decide whether to appoint defense counsel, but rather, the issue turned on whether to let assigned counsel withdraw from the case. The defendant, Barayagwiza, had proclaimed that the ICTR lacked the degree of independence and impartiality required to hold a fair trial and had refused to attend court because the proceedings were, in his view, a sham. ${ }^{93} \mathrm{He}$ had also instructed his assigned counsel not to attend the trial or any of the court proceedings on his behalf. ${ }^{94}$ This refusal had prompted assigned counsel

90. See Milošević, Reasons for Decision on Assignment of Defence Counsel, supra note 40 , 91 65-66.

91. Id.

92. Id. Tा 39-41.

93. See Barayagwiza, Decision on Defense Counsel Motion to Withdraw, supra note $4, \rrbracket 12$.

94. Id. 
to file a motion to withdraw due to their stated ethical obligation to follow the instructions of their client in decisions about presenting the defense. ${ }^{95}$

The ICTR Trial Chamber, interestingly presided over by a judge from South Africa's mixed legal system, unanimously ruled that assigned counsel did not only owe a duty to the defendant but also to the tribunal. $^{96}$ Part of assigned counsel's greater duty towards the court included ensuring a fair and expeditious trial, and defending their client's interests in an adversarial trial, with or without instructions on how to do so. ${ }^{97}$ The judges reasoned that, given the gravity of the charges, they had a higher duty to ensure the protection of the defendant's rights in light of what was at stake for him. ${ }^{98}$ Consequently, their obligation to protect the rights of the defendant and to maintain the overall fairness of the proceedings trumped Barayagwiza's assertion of the right to control his defense. In fact, the judges felt that this duty even displaced the duty of defense counsel-who were also officers of the court-to listen exclusively to Barayagwiza. ${ }^{99}$

In a compelling concurring opinion to the denial of counsel's request to withdraw, Judge Gunawardana, the common law judge, relied on U.S. case law to suggest what might have been the better solution. ${ }^{100}$ He wrote that he would have allowed assigned counsel to withdraw and appoint standby counsel for Barayagwiza instead. ${ }^{101}$ This approach would have avoided the entangling of obligations between the defendant's counsel as lawyers for the accused and the duties that they owed the court in their capacity as defense counsel. This approach would have also permitted counsel in court to represent Barayagwiza in proceeding along the best course of action, even in light of contrary orders from the defendant. In his view, the interests of justice dictated that the independence of standby counsel be preserved over the ethical obligations of appointed counsel. ${ }^{102}$

The Norman case before the SCSL involved a defendant attempting to follow Milošević's example and proceed to trial without counsel. The

95. See id. $\uparrow 17$.

96. Id. I 21. Judge Pillay (South Africa), former president of the ICTR and current UN commissioner for human rights, was the presiding judge of Trial Chamber I. The other judges, Erik Møse and Osaka de Zoysa, were from Norway and Sri Lanka, respectively.

97. See id.

98. Id. $\mid 23$.

99. Id. $\ 24$.

100. See Barayagwiza, Decision on Defense Counsel Motion to Withdraw, supra note 4 (Gunawardana, J., concurring).

101. Id. (Gunawardana, J., concurring).

102. Id. 
Trial Chamber of the SCSL, however, rejected Norman's request to proceed on his own for two main reasons. The first reason was the timing of Norman's request, which was made on the first day of trial. ${ }^{103}$ The Court ruled that granting the defendant's request to represent himself before the tribunal would require an enormous delay in the proceedings to both give him time to prepare and then conduct the trial unrepresented by counsel. ${ }^{104}$ The second reason was that Norman was not in the case alone; he was jointly being tried with two others. In those circumstances, the SCSL Trial Chamber determined that permitting Norman to proceed without any assistance of counsel would result in extreme unfairness to his two co-defendants, both of whom had retained counsel for the trial. ${ }^{105}$

In reaching this conclusion, the Court considered a number of factors including the necessity of counsel to a fair and expeditious trial, the extreme complexity of the case in question, the public interest in having the trial continue in an expeditious manner, and the potential disruption of the proceedings arising from Norman's request. ${ }^{106}$ In the end, the chamber determined that the defendant would be required to accept standby counsel if he wanted to proceed in conducting his own defense. ${ }^{107}$ The interests of justice, the Chamber held, required that the judges not allow Norman to continue entirely without any legal assistance. $^{108}$

Just before the start of his trial, on July 6, 2004, in the same Sierra Leone Tribunal, another defendant-Gbao-applied to terminate his counsel on the basis that he did not recognize the legitimacy of the SCSL and did not therefore wish to participate in his case. ${ }^{109}$ The Trial Chamber ruled that his explanation offered for seeking the withdrawal of his counsel was insufficient to constitute the exceptional circumstances required by the rules to grant his request. ${ }^{110}$ The court reasoned that, after an examination of the circumstances of his case, the interest of justice would not be served by permitting Gbao to be unrepresented before the Court. ${ }^{111}$ The judges considered it their duty to safeguard his

103. Norman, Decision on the Application of Samuel Hinga Norman for SelfRepresentation, supra note 24, $1917-20$.

104. Id.

105. Id. $91913-16$.

106. Id. $\ 26$.

107. Id. $\ 32$.

108. Id. $\$ 30$.

109. Prosecutor v. Gbao, Case No. SCSL-04-15-AR73, Decision on Appeal against Decision on Withdrawal of Counsel (Nov. 23, 2004), available at http:/www.worldcourts.com/scsl/eng/decisions/2004.11.23_Prosecutor_v_Sesay_Kallon Gbao.PDF.

110. Id. $\ 29$.

111. Id. $\$ 46$. 
rights and the integrity of the proceedings by insisting that counsel represent him. ${ }^{112}$ Furthermore, the accused, according to the Chamber, could not waive his right to a fair and expeditious trial. ${ }^{113}$ The court therefore ordered the defense team to represent him to the finality of the case. Gbao then sent a declaration to the judges the next day, indicating that he was boycotting court. He then appealed the decision. ${ }^{114}$ The Appeals Chamber upheld the trial level decision. ${ }^{115}$ Interestingly, both groups of judges at the trial and on appeal implied that the right to counsel cannot be viewed in isolation from other rights that the defendant enjoyed. The right to have counsel had to be counterbalanced against Gbao's right to an expeditious trial.

The SCSL is also the site of another relatively recent decision on this topic, which occurred at the outset of the Taylor case in June 2007. The accused, former President of Liberia Charles Taylor, did not appear in court on the day of the prosecution's opening statement. ${ }^{116}$ Taylor did not believe that his defense team had been given adequate time, resources, or personnel by the SCSL to hold a fair trial. He therefore dismissed his entire defense team, refusing to allow them to represent him in court, and wrote a letter announcing his intention to appear in his own himself. ${ }^{117}$

In response to what it later termed a "boycott" of the proceedings, the chamber ordered that lead counsel remain to represent the accused Taylor in his absence. ${ }^{118}$ Taylor's defense counsel, much like Barayagwiza's lawyers at the ICTR, retorted that it would be unethical for him to purport to represent Taylor without instructions and against his former client's wishes. Khan was wrong on the applicable law in the sense that the code of conduct in the tribunal trumps the rules of his national bar. Under the Court's rules, he was required to follow the judicial order whose effect would have been to change his status from administratively assigned counsel to court appointed counsel. But he did not relent, even after he was threatened with potential contempt of court if he departed the courtroom because of violation of the chamber's order to remain and to represent Taylor. ${ }^{119}$

Left without both a defense counsel and without a defendant, the court appointed duty counsel from the Office of the Principal Defender, a

112. Id.

113. Id.

114. Id. ๆๆ $44,48,50$.

115. Id. ๆๆ 53, 60 .

116. Taylor, Transcript of Record, supra note 28 , at 244 9ा 10-12.

117. Id. at 250 १ा 15-29, 251 १ๆ 1-8.

118. Id. at 259 q $1-18$.

119. Id. at 263 १ๆ $2-3$. 
lawyer employed by the SCSL Defense Office, to take over the defense case temporarily for the duration of the opening statement. ${ }^{120}$ Consistent with that tribunal's practice, duty counsel had been attached to the case, but only in a limited role prior to that moment. This implied that he did not have access to case materials, including the prosecution discovery, since private counsel had already been provisionally assigned to represent the defendant. ${ }^{121}$ The court's decision raised important questions regarding how the sole staff member of a poorly resourced Defense Office in The Hague Sub-Office of the SCSL could face an array of experienced prosecutors to assist the accused during his selfrepresentation. The decision also exposed the issue alluded to above when senior court officials purported to instruct the court-appointed duty counsel on his role in a way that raised concerns about the overall fairness of the process towards the defendant and ultimately led to his decision to resign from the tribunal.

Ultimately, Trial Chamber II did not permit Taylor's request to conduct his own defense. In a seemingly hasty June 25, 2007 ruling, at least when compared to the ICTY chamber's cautious approach to the interpretation of that right in Milošević, the three SCSL judges, all from common law jurisdictions, ruled that a defendant choosing to represent himself had to be present in court in order for the right to be validly asserted. ${ }^{122}$ The court basically refused to allow Taylor to choose if and when to appear before them and instead required that a new defense team be composed to handle his defense case. ${ }^{123}$ This decision raised concerns about what judges should do in such circumstances where the absence of a defendant is apparently predicated on the belief that he would not get a fair trial, but at the same time, was clearly not spurious because it was a protest of the tribunal registrar's decision not to afford him adequate resources to prepare his defense. The added difficulty, from the defendant's perspective, was the chamber's abject refusal to give counsel sufficient time to prepare his case before the opening of his scheduled trial. In other words, at what point is a supposedly self-representing defendant like Taylor allowed to boycott court proceedings to make a point without risking termination of his prima facie right to defend himself in person?

120. Id. at 267 ๆा 10-11.

121. For example, duty counsel, as the Head of The Hague Sub-Office of the Principal Defender in the SCSL, did not have access to disclosure materials from the prosecution, nor was he involved in the defense strategy prior to the events of June 4, 2007. In the interest of transparency, this author was the Court appointed counsel for Taylor.

122. Taylor, Transcript of Record, supra note 28 , at 380 ๆๆ 21-29, 381 ๆศ 1-6.

123. Id. 
In the end, the Trial Chamber, having ordered that new private counsel be assigned to Taylor, delayed the trial by almost five full months to give the defense team adequate time to review the disclosure and prepare their client's defense before the first prosecution witnesses were called to the stand. ${ }^{124}$ Ironically, had the same judges given the defense counsel and the accused three additional months to prepare for the opening of the prosecution's case, that major delay in the opening of the trial could have been easily avoided.

Taken together, this sampling of four important cases from the ad hoc tribunals demonstrates the various ways that international penal courts have weighed the decision whether or not to assign counsel over the defendant's wishes. Each court eventually made the decision to impose some form of counsel based on the interests of justice. The Milošević court at the ICTY initially fretted over preservation of the defendant's rights but later became very concerned with the expediency of the trial and the undue delay that allowing him to continue without counsel would cause. In Barayagwiza, the ICTR was primarily concerned with balancing the defendant's rights against ensuring the trial's inherent fairness and continuity. In the Norman and Gbao cases at the SCSL, the judges considered the expediency of the trial, its overall fairness given his two co-defendants at trial, and various other factors. Yet in Taylor, a different group of judges than in the Norman case effectively assumed that the defendant was seeking to manipulate the proceedings-as the prosecutors had claimed. The Taylor Trial Chamber therefore qualified the defendant's right to represent himself without much further deliberation or giving the defendant the opportunity to clarify his actual position. For instance, the judges could have instead invited Taylor to attend court and to show cause as to why counsel should not be imposed on him. Such an invitation would have given him an opportunity to be heard before this fundamental right was taken away.

At the same time, this qualification of the defendant's right might have been the common sense solution because there had already been enough delays in that trial. It is also true that, unlike the ICTY and ICTR, the SCSL was under significant pressure to conduct its trials in a shorter time frame. Thus, extraneous considerations might have been influential to the final judicial decision. Whatever the case, there was apparently little judicial appetite to cater to the demands of a defendant that the prosecutors basically charged was simply being manipulative. The chamber also saved scarce resources, in the notoriously cash trapped donations based court, and moved the trial process forward when it 
ordered appointment of competent counsel. This was what Taylor really wanted. Indeed, the accused, for his part, never complained about the forfeiture of his right of self-representation; as he seemed happy enough to get the quality defense team that he had always wanted to be assigned to represent him in the first place.

In the result, unlike the ICTY's stance in Milošević, the stance taken by the SCSL and ICTR trial chambers in Norman, Gbao, Taylor, and Barayagwiza were similar. Each chamber basically determined that the defendants were either boycotting the proceedings, after choosing to absent themselves from the trial, concluding that their decisions to terminate counsel without informing the tribunals were attempts to obstruct the proceedings. The difference between these decisions and the rulings of national courts faced with similar situations seems, at least partially, like a striking reflection of the larger goals of international criminal justice and the influence of civil law thinking. Consider the recent multi-accused case of Regina v. Iqbal before the English Court of Appeal Criminal Division during which one defendant became dissatisfied with his appointed counsel leading to an alleged breakdown in their relationship. ${ }^{125} \mathrm{He}$ requested a change of counsel, but did not provide the court with a substantial reason to justify his decision to change his form of representation. The judge ended up requiring that Iqbal, if he wanted to dispense with counsel, represent himself during the trial. ${ }^{126}$

This ruling stands in stark contrast to the SCSL decision in Norman. The U.K. court was seemingly unconcerned with the unfairness that might arise for Iqbal's five co-defendants. Rather, it cited the risks of allowing intentional delays of trial by approving unjustified changes to assigned counsel as the primary consideration. Additionally, the appeals court actually considered the interests of the five represented codefendants as a reason to allow Iqbal to continue without counsel. ${ }^{127}$ Because the other defendants would be represented, there was less danger from Iqbal unduly slowing or disrupting the course of the trial. It seems plausible that the Norman Trial Chamber could have reached a similar conclusion, considering that it had also ordered Norman to be assisted during courtroom proceedings by the court-appointed duty counsel who was a lawyer from the Defense Office.

125. R. v. Iqbal, [2011] EWCA (Crim.) 1294 (Eng.), 2011 WL 1151103 (Mar. 23, 2011).

126. Id. $9917,19,23$.

127. Id. $\uparrow 30$. 
The case of U.S. v. Vernier, ${ }^{128}$ recently heard before the U.S. Court of Appeals for the Fifth Circuit, presents a second good contrast with the balancing process at the international level. In that case, the defendant Vernier told a third party that he intended to disrupt his trial and make a political statement. However, the court denied his request to proceed to trial without representation. ${ }^{129}$ This decision highlights the importance to the ICTY of maintaining the appearance of a just trial in the Milošević case. Milošević had also commented to the media about the legitimacy of both the tribunal and his upcoming trial. Given his comments, his health, and the considerably larger stage from which the trial would be conducted, the threat of disruption from Milošević was as great, if not greater, than the threat of disruption posed by Vernier.

There are several possible explanations why the ICTY demonstrated greater leniency towards Milošević as compared to the Fifth Circuit's treatment of Vernier. The goals of the court shift based upon what is at stake for each respective defendant. The Milošević Court was considering charges of genocide and crimes against humanity, some of the worst crimes of which a person can be accused. The Vernier Court was dealing with a defendant accused of a car-jacking that resulted in a person's death, which is serious, but relatively less so when compared to the mass scale nature of international crimes in which thousands and thousands typically die. ${ }^{130}$ As the scale of crime becomes less severe, the court's concern with maintaining the continuity of the trial and refusing to allow the defendant's tactics to delay justice becomes greater.

Additionally, compared to the Fifth Circuit Court of Appeals and those of other national jurisdictions, which have established legitimacy due to a long legal tradition, international penal courts, which are a newer phenomenon, are seemingly more concerned with maintaining the appearance of legitimacy for their verdicts. Moreover, the Milošević case was the first major case in which the issue of self-representation confronted international criminal tribunal judges, and the hotbed of issues facing international courts and their legitimacy makes respect for the rights of the defendant even more critical.

At the same time, much like many national courts that do not tend to countenance a recalcitrant defendant's attempt to manipulate the justice system, the countervailing consideration is that international penal tribunals should not allow the accused to manipulate the ground rules to undermine victims' confidence in the process and ultimately to avoid facing justice. That said, in addition to the previously cited factors, the

128. United States v. Vernier, 381 F. App'x 325 (5th Cir. 2010).

129. Id. at 327.

130. Although, Vernier was sentenced to life imprisonment. 
relative leniency may partly be a function of international criminal trials being expected to operate at a higher level of respect for defendant rights vis-à-vis domestic trials because international tribunals are often intended to serve as models of fairness for national courts. Strict concern to ensure compliance with the fair trial provisions mandated by international human rights law, such as those found in ICCPR Article 14, appears to influence judges to treat defendants with greater sensitivity. The high visibility and media interest generated by high profile international cases also creates some inevitable pressure for the system to function above board. The careful balancing required of international criminal tribunals, therefore, results in what appears to be greater leeway than one would find granted within a domestic appellate or other court.

A final basis for comparison comes from the trial that arose from the appeal in Clark v. Perez. ${ }^{131}$ In that case, the court allowed the defendant Clark to represent herself during the trial. The trial judge warned her, however, that if she was disruptive during the course of the trial, she would be removed from the court and the trial would continue in her absence. ${ }^{132}$ On the first day of trial, Clark explained to the jury that she did not believe the court or the trial was legitimate, and, therefore, she would not participate. ${ }^{133}$ After she departed the court, the trial continued in its entirety with no one seated at the table for the defense. $^{134}$ The judge did not appoint anyone to represent Clark's interests, but did allow the defendant to follow the remainder of the trial through a radio transmission to her holding cell. ${ }^{135}$

Proceeding with the trial while no one represented the defendant is an option the ICTY, ICTR, and the SCSL never even considered in Milošević, Barayagwiza, Norman, Gbao, and Taylor, and with good reason. The goals of the international penal courts could not have been fulfilled had those defendants been convicted without being either present or represented by some counsel. Beyond the obvious detriment to the overall fairness of the trial, there could be limited possibility to help foster national healing or reconciliation if an international tribunal simply rehashed the crimes of the accused and convicted him without anyone at court trying to present his side of the story.

The rationale that a defendant must be afforded every possible chance to give his side of the story is similar to that of civil law systems that are willing to override the accused person's wishes through the

131. Clark v. Perez, 510 F.3d 382 (2d Cir. 2008).

132. Id. at 386 .

133. Id. at 387.

134. Id.

135. Id. 
imposition of counsel whenever deemed necessary. In a way, this logic may represent the meeting point between the civil and common law systems given Chief Justice Burger's admonition in Faretta that criminal justice systems should not permit themselves to be used by defendants, who against all common sense forgo the assistance of counsel as a way to achieve self-destruction, or, as Justice Blackmun put it in his dissent in the same case, as a vehicle for "personal or political self-gratification.",136

Sometimes, preserving fairness means restricting the autonomy of the defendant as the court did in the ICTR and the SCSL. At other times, as in the ICTY, especially in Milošević, the international courts deferred to the defendant's wishes to a far greater extent than one would expect to see on the national level. The most distinct and noticeable difference in the decisions reviewed above is the willingness of the national courts to allow defendants to dig their own grave, so to speak. In Iqbal, for example, the court responded to the defendant's frivolous complaints by requiring him to go through trial alone. The Perez court similarly let the trial proceed without any defense being presented at all, simply because that was the way the defendant wanted it. These kinds of problematic decisions may be justifiable at the municipal level, but not so at the international level given that the defendants in the latter setting are often charged with heinous international crimes such as genocide, crimes against humanity, and war crimes.

One possible noteworthy exception to this observation can be found in the Statute of the Lebanon Tribunal, which, going against the grain of the ICTR's Barayagwiza ruling and international criminal tribunal experience generally, allows for the possibility of trials in absentia. ${ }^{137}$

136. Faretta v. California, 422 U.S. 806,849 (1975).

137. Article 22(1) of the Statute for the STL reads:

The Special Tribunal shall conduct trial proceedings in the absence of the accused, if he or she:

(a) Has expressly and in writing waived his or her right to be present;

(b) Has not been handed over to the Tribunal by the State authorities concerned;

(c) Has absconded or otherwise cannot be found and all reasonable steps have been taken to secure his or her appearance before the Tribunal and to inform him or her of the charges confirmed by the Pre-Trial Judge.

Statute of the Special Tribunal for Lebanon art. 21(1), S.C. Res. 1757, Attachment, U.N. Doc. S/RES/1757, at 20 (May 30, 2007) [hereinafter STL Statute]. While the above requirements of the statute appeared to be cumulative, Rule 106(A) of the STL Rules of Procedure and Evidence, adopted by the judges on March 20, 2009, essentially reproduced the content of Article 22. However, Rule 106(A) introduced two significant amendments imposing "a reasonable time" requirement for the handing over of a suspect and the phrase "or" was introduced obviously to permit the STL to proceed with in absentia trials where only one of the three requirements enshrined in the statutory provision is met. The question is whether the United Nations and Lebanon, the drafters of the STL Statute, should have amended the statute in this way instead of judges 
This is an exception to the general rule, which in practice may prove to be so challenging that the international community might choose to abandon this strategy. The Statute, however, provides several checks to ensure that a modicum of fairness is maintained. The accused must have been given notice of the trial proceeding in his absence, and counsel must have been appointed by either the defendant or the Court. ${ }^{138}$ As a result, whether the accused is present or not, the STL Statute does not allow for a Perez situation where the defense table in the courtroom remains empty.

Additionally, the STL Rules of Procedure and Evidence guarantee that, if an absent defendant appears before the conclusion of the trial, he is automatically granted the right to have a retrial if certain preconditions are fulfilled. ${ }^{139}$ This said, this right is only guaranteed once. ${ }^{140}$ The provision for trials in absentia reflects the civil law tradition more strongly than any previous international court. ${ }^{141}$ Furthermore, the use of trials when the defendant is absent was included as part of the Special Tribunal because Lebanon's domestic legal system follows the civil law tradition and the STL reflects those practices. ${ }^{142}$ However, the prospect of in absentia trials has already been the subject of significant criticism. Indeed, based on rulings by the Human Rights Committee and the European Court of Human Rights, strong grounds exist to argue that the STL provision is a violation of international human rights norms-an argument that the tribunal judges will likely resist. ${ }^{143}$

There is also concern that the provisions for providing notice to the accused and for granting a retrial are insufficient to protect the rights guaranteed by the ICCPR. ${ }^{144}$ Consequently, there is further concern that the legitimacy of the STL will subsequently erode abroad, and perhaps

stepping into the arena of legislators and doing so themselves. See id:; STL RPE, supra note 20. For an application of these provisions in deciding to proceed with in absentia trials against four suspects, see Prosecutor v. Jamil Ayyash, Case No. STL-1l-O1/I/TC, Decision to Hold Trial in Absentia (Feb. 1, 2012).

138. STL Statute, supra note 137, art. 22(2).

139. STL RPE, supra note 20, R. 108.

140. Id.

141. See U.N. Secretary-General, Report of the Secretary-General on the Establishment of a Special Tribunal for Lebanon, ๆ 8, U.N. Doc. S/2006/893 (Nov. 15, 2006).

142. Id. ๆ 32 .

143. See Chris Jenks, Notice Otherwise Given: Will in Absentia Trials at the Special Tribunal for Lebanon Violate Human Rights?, 33 FORDHAM INT'L L.J. 57, 61-62 (2009).

144. It is worth noting that the STL is not purely an "international" court in the same way as the ICTY or ICTR because it was created by an agreement with the country of Lebanon. This distinction explains some of the divergence from the rules of the two purely international tribunals. See Fausto Pocar, The Proliferation of International Criminal Courts and Tribunals: A Necessity in the Current International Community, $2 \mathrm{~J}$. INT'L CRIM. JUST. 304, 305 (2004). 
even within Lebanon, if the option of in absentia trials is given effect in cases that are eventually tried. ${ }^{145}$ Admittedly, such conclusions are probably speculative at this point in the absence of actual trials in that court. Nevertheless, even in the first cases in which this controversial in absentia trial regime was approved recently, the appointment of permanent counsel to represent the accused was deemed necessary. In one such case, appointment of permanent counsel occurred the very next day, although it is uncertain how the eight assigned lawyers in that case will mount a defense for suspects with whom they cannot presumably communicate. ${ }^{146}$

Each of the above tribunal decisions demonstrates the importance the international courts place on maintaining the perception of complete fairness and a just trial. At the national level, however, courts are far more likely to restrict the autonomy of the defendant to ensure the trial progresses forward without disruption. Part of the reason for this distinction, to reiterate the point, is that international trials have to establish both the legality and legitimacy of their actions. International courts are widely seen as backup systems that, in the language of the ICC statute, that will only come to apply in situations of inactivity and when the national jurisdictions are unwilling and/or unable to prosecute. ${ }^{147}$

One aspect of the civil law system that the majority of international tribunals seem to have adopted is the belief that it is not always up to the defendant to protect his own rights at trial. Even though Barayagwiza, Norman, Gbao, and Taylor all tried to take steps that would have seriously harmed their chances of acquittal, the courts refused to allow them to impair the appearance of total fairness. Instead, much like in the civil law system, the court assumed a more proactive stance and required the defendants to make use of legal counsel in order to facilitate a fair and expeditious trial. This assumption perhaps represents an international belief that both truth and justice are vital objectives to be achieved. On the other side of the coin, decisions such as those in Norman and Barayagwiza have become more common after the ICTY received trenchant criticism for apparently bending over backwards to accommodate Milošević. There is ample literature confirming a general

145. Jenks, supra note 143 , at 97.

146. See Prosecutor v. Jamil Ayyash, Case No. STL-1l-O1/I/PTJ, Assignment of Counsel for Proceedings Held in Absentia Pursuant to Rule 106 of Rules (Feb. 2, 2012) (assigning lawyers to represent the suspects in their absence based upon the request of the pre-trial judge); see also Press Release, Special Tribunal for Lebanon, Assignment of Permanent Counsel (Feb. 2, 2012), available at http://www.stl-tsl.org/en/media/pressreleases/02-02-2012-assignment-of-permanent-counsel.

147. Rome Statute, supra note 16, art. 17. 
feeling among scholars that Milošević's dilatory tactics were seen as having robbed his alleged victims of the chance to see justice done.

\section{B. Should the Court Appoint Standby or Amicus Curiae Counsel?}

The second question that courts at both the international and national level often face is the choice between standby counsel and amicus counsel. The most pertinent comparison within international jurisprudence on this subject is between the aforementioned Miloševic and $\check{S} e s ̌ e l j$ cases. One important principle that both of the chambers utilized and established as part of international criminal procedure is the proportionality principle.

The ICTY Appeals Chamber first invoked this principle in Milošević in an attempt to temper the modalities order of the Trial Chamber in their appointment of defense counsel. ${ }^{148}$ The appeals court ruled that the appointment of counsel, while appropriate, had gone too far in completely divesting control of the trial from Milošević. ${ }^{149}$ The proportionality principle dictated that the trial judges could only restrict Milošević's right to conduct his own defense to the minimum extent necessary to accomplish the objective of ensuring a fair and expedient trial. ${ }^{150}$ The Appeals Chamber, therefore, ruled that any time Milošević's health allowed him to attend a court proceeding, the judges must allow him to handle his own case. ${ }^{151}$ The assigned counsel would only take over when he was unable to attend. In a sense, the appeals judges placed the appointed defense counsel into a super-standby counsel role. This decision essentially indicated that the risk of disruption was only sufficient to move from using amicus curiae to standby counsel, rather than stripping Milošević of the right to defend himself entirely.

The Trial Chamber in Šeselj referred to the same proportionality principle. $^{152}$ The court used the principle to consider the effect of his numerous pre-trial disruptions. Before requesting to proceed without counsel, Šešelj had made numerous public statements declaring his intent to cause trouble and disrupt the proceedings. ${ }^{153}$ Due to the threat of disruption these statements provided, the ICTY Trial Chamber determined that standby counsel was a more appropriate form of

148. See Milošević, Decision on Interlocutory Appeal of the Trial Chamber's Decision on the Assignment of Defense Counsel, supra note 25, $\| 18$.

149. See id. 16.

150. See id. 17.

151. See id. 19.

152. See Šešelj, Decision on Assignment of Counsel, supra note 36, qๆ 46-51.

153. See id. $\uparrow 30$. 
restriction on Šešelj than simply appointing amicus curiae as the court had done for the Milošević trial. ${ }^{154}$

The more interesting decision in the Šešelj case came later when the Appeals Chamber removed standby counsel based on a complaint raised by the defendant. ${ }^{155}$ After the trial began, the court had tried to assign defense counsel to the accused and terminated his right to conduct his own defense. When the appellate court reversed that position because it required a warning to be issued first, the trial judges re-assigned standby counsel. ${ }^{156}$ The Appeals Chamber controversially agreed with the defendant, ruling that the lower court's action had undermined their previous decision reinstating his right to conduct his own defense. ${ }^{157}$ The appeals judges determined that, despite his disruptions, their prior decision had wiped the slate clean. Consequently, Šešelj deserved to continue to conduct his defense without restriction until his behavior demonstrated that such a restriction was necessary. ${ }^{158}$

This decision, if followed, appears to be favorable to selfrepresenting defendants. However, it creates a troubling precedent for future international penal tribunals. The trial court considered Šešelj's past actions in making their decision at the beginning of the trial to appoint standby counsel. Then, halfway through the trial, the Appeals Chamber ruled that his past actions up to that point were not grounds for the imposition of standby counsel upon his rights. Perhaps the judges were concerned with mitigating the hunger strike that the defendant had engaged upon in protest. Be that as it may, while the appeals judgment would usually carry significantly more weight, consideration of past behavior and the threat of disruption have generally continued to guide the appointment of standby counsel at the international level. At the national level, in both common law and civil law jurisdictions, given Šešelj's previous courtroom antics, counsel would have been imposed on the defendant irrespective of what his wishes were.

These decisions reflect the need for the widely accepted "balancing test" that courts apply in the United States to decide how much autonomy to allow a defendant in running the defense. Courts will weigh the prejudice to the defendant's legitimate interests against the potential

154. See Šešelj, Decision on Prosecution's Motion for Order Appointing Counsel to Assist Vojislav Sešelj with His Defence, supra note 4, ๆ 30.

155. See Prosecutor v. Šešelj, Case No. 03-67-AR73.4, Decision on Appeal Against Trial Chamber's Decision (No. 2) on Assignment of Counsel (Int'l Crim. Trib. for the Former Yugoslavia Dec. 8, 2006) [hereinafter Šešelj, Decision on Appeal Against Trial Chamber's Decision (No. 2) on Assignment of Counsel].

156. See id. ๆ 3.

157. See id. $\llbracket 26$.

158. See id. $\llbracket 27$. 
disruption to the trial proceedings. ${ }^{159}$ As part of that assessment, courts will consider 'the defendant's reasons for the self-representation request, the quality of counsel representing the party, and the party's prior proclivity to substitute counsel.,"160

Standby counsel is the much more widespread solution to balancing these interests in the United States when allowing a defendant to conduct his own defense. The Supreme Court in Faretta specifically referenced standby counsel as an allowable restriction even over the defendant's objection. ${ }^{161}$ Similarly, in McKaskle v. Wiggins, the highest court upheld the lower court's appointment of standby counsel to help guide a defendant through courtroom procedure, thus relieving the judge of that responsibility. ${ }^{162}$ It seems to have been accepted in U.S. courts that standby counsel is preferable because they are both more able to effectively assist a pro se defendant during the course of trial and can also more easily step in to take over the defense should it become necessary during trial.

Given the influence of the civil law tradition, however, the logic of the U.S. experience is not entirely reproducible within an international court. This is because, in the civil law, counsel's main goal is not necessarily to defend and protect the defendant's interests but is aimed at assisting or guiding the defendant in presenting his story to the court. Lawyers in the civil law tradition are more restricted in acting without specific instructions from a defendant. It is therefore problematic for standby counsel to take over a case for a defendant at international law without either a mandate or instructions from the defendant on how to proceed with the defense. ${ }^{163}$ Due to this problem, depending on the unique facts of each case, amicus curiae may well be a relatively better option at international law.

Amicus curiae could assist the court to avoid having the defense depend entirely on the decisions of defendants more interested in making political statements to domestic constituencies than actually refuting prosecution allegations or making their own case. Moreover, given the complexity and length of international criminal trials, having amicus counsel assist the court with many different issues that arise is perhaps

159. See United States v. Pickett, 387 F. App'x 32, 34 (2d Cir. 2010).

160. Id.

161. Faretta v. California, 422 U.S. 806, 834 n.46 (1975).

162. See McKaskle v. Wiggins, 465 U.S. 168, 196-97 (1984).

163. See Jarinde Temminck Tuinstra, Assisting an Accused to Represent Himself: Appointment of Amici Curiae as the Most Appropriate Option, 4 J. INT'L CRIM. JUST. 47, $52(2006)$. 
more helpful and necessary to ensuring a fair trial than is the case in a typical criminal trial in the United States. ${ }^{164}$

In a messy and disrupted international trial, there may be significant advantages to having an independent amicus voice helping to protect the defendant's interests rather than standby counsel, who are necessarily required to continue on behalf of the accused. In the former situation, the defendants have limited control over counsel, whereas in the latter scenario, they could choose to stop cooperating with standby counsel and use that as a trump card to undermine the actual process and even perhaps its legitimacy. Whatever decision an international court makes must be proportional. This helps to ensure that any limitation or infringement on the defendant's right will only be to the extent necessary to preserve a fair and expeditious trial.

\section{Options upon Removal of the Disruptive Defendants}

The final question faced by international criminal tribunals is what action should be taken when a defendant, either with or without representation, is so disruptive that he has to be removed, or is absent from the proceedings. The question of what to do when a defendant has representation but is not present on a particular occasion is fairly well settled. In both national and international law, with a few minor exceptions, courts usually are able to proceed with the trial as long as the defendant's counsel is able to represent him. While there is a principled guarantee in the ICCPR that the defendant will be present at trial, courts have restricted this right as long as a warning is given to the defendant that the trial will proceed in his absence. ${ }^{165}$

To bypass the right to be present, courts typically consider defendants to have waived the right. ${ }^{166}$ The ICTR amended its Rules of Procedure and Evidence in May 2003 to include Rule 82 bis to explicitly recognize this possibility. ${ }^{167}$ The ICTY and SCSL also explicitly allow

164. See id. at 62-63.

165. See Šešelj, Decision on Prosecution's Motion for Order Appointing Counsel to Assist Vojislav Šešelj with His Defence, supra note 4, \ 30.

166. Prosecutor v. Barayagwiza, Case No. ICTR-99-52-A, Appeals Chamber Judgement, ๆๆ 95-100 (Nov. 28, 2007); Prosecutor v. Gbao, Case No. SCSL-04-15-T194, Ruling on the Issue of the Refusal of the Third Accused, Augustine Gbao to Attend Hearing of the Special Court for Sierra Leone on 7 July 2004 and Succeeding Days, I 3 (July 12, 2004); Taylor, Transcript of Record, supra note 28, at 258.

167. If an accused refuses to appear before the Trial Chamber for trial, the Chamber may order that the trial proceed in the absence of the accused for so long as his refusal persists, provided that the Trial Chamber is satisfied that: (i) the accused has made his initial appearance under Rule 62; (ii) the Registrar has duly notified the accused that he is required to be present for trial; and (iii) the interests of the accused are represented by counsel. ICTR RPE, supra note 21, R. 82 bis. 
the court to remove defendants from the courtroom and continue in their absence so long as a warning has been given. ${ }^{168}$ The notion of waiver, of course, permits a non-disruptive defendant to take a sick day or to be absent from court for good reasons such as ill health while giving his principled indication that the trial may proceed.

Similarly, as discussed previously, Article 63(2) of the Rome Statute of the ICC also permits the trial chamber to order the removal of a disruptive defendant from the court as a last resort. However, in such cases, Article 63(2) mandates alternative ways for him to observe the trial and to instruct counsel from outside the courtroom. American courts have frequently employed telecommunications technology to allow defendants who have been removed to view or listen to court proceedings, even when they are not physically present. ${ }^{169}$ This approach has also been similarly utilized in the tribunals. Video recordings and transcripts of proceedings are typically made available so that defendants may view them at their leisure. ${ }^{170}$

The more problematic situation arises when the defendant does not have defense counsel available or when defense counsel is removed from court for disruption or when the defendant refuses to come to court. Perhaps the best ICTY example of a pro se defendant simply not showing up for trial is the Karadžić case. ${ }^{171}$ The defendant in that case believed that he should be given significantly more time to prepare his defense than the court had allowed and refused to attend court proceedings until he felt prepared. The Trial Chamber ruled that the interests of justice required the court delay the beginning of trial to give appointed defense counsel time to adequately prepare. As it turned out, by the time appointed counsel was ready to continue, so was Karadžić, and the court allowed him to continue handling his own defense while maintaining the previously appointed lawyers as standby counsel. ${ }^{172}$

Again, a comparison with national decisions demonstrates the concern at the international level with preserving the perception of fairness in trials of those accused of heinous international crimes. The

168. See ICTY RPE, supra note 21, R. 80; see also SCSL RPE, supra note 21, R. 80.

169. See Clark v. Perez, 510 F.3d 382, 387 (2d Cir. 2008) (discussing a trial judge's decision to allow defendants to listen to proceeding from a holding cell); see also Torres v. United States, 140 F.3d 392, 397 (2d Cir. 1998) (discussing defendant's choice to listen to proceeding from a holding cell).

170. The requirement of a video link for defendants removed from Court is actually codified in the SCSL Rules of Procedure and Evidence. See SCSL RPE, supra note 21, R. 80.

171. Karadžić, Decision on Appointment of Counsel and Order on Further Trial Proceedings, supra note $26, \uparrow 1$.

172. See Prosecutor v. Karadžić, Case No. IT-95-5/18-T, Decision on Designation of Standby Counsel, ๆf 8-10 (Int'l Crim. Trib. for the Former Yugoslavia Apr. 15, 2010). 
defendant in Karadžić essentially handcuffed the court into delaying the trial unless they chose to proceed with no one representing the defendant. The chamber either had to succumb to the defendant's demands and delay trial so that he could prepare, or they had to delay trial to give appointed counsel time to prepare.

Defendants seemingly gain more time to prepare by refusing to come to court than when they do in fact attend. This maybe a function of ad hoc tribunal judges being under some pressure to keep the trials on some sort of schedule, especially given the usual length of international cases, meaning that deviations from the forecasted timelines meet with a healthy dose of skepticism. Ad hoc tribunals thus hesitate to grant delays favoring defendants that could lead to both internal and external criticism, especially in the face of their respective completion strategies. When it is possible to blame the delay on the defendant, after a defendant has boycotted the proceedings, then they seem willing to make the decision to restore the defendant's participation. The irony is that, in at least two instances, such as the opening and closing of the Taylor case at the SCSL, giving the defense more time to prepare would have obviated the later need for defendants to threaten to boycott the proceedings.

A question thus arises whether the tribunal judges are acting fairly in dealing with such defense requests or whether they are tainted with the typical prosecution argument that the defendants are being nothing more than dilatory rather than asserting a legitimate request. The same may have been true in the Karadžić case at the ICTY. It remains to be seen whether future trials, especially at the ICC, which in a few years will likely be the last court standing, will be more sympathetic to defendant requests for more time to review the often-large disclosure dumped on them by tribunal prosecutors thereby eliminating the need for accused persons' refusal to attend court in at least some of the cases.

In contrast, U.S. courts are not nearly as willing to be challenged by a defendant into allowing delays in trial proceedings. A good example is Davis v. Grant, argued before the Court of Appeals for the Second Circuit in 2008. ${ }^{173}$ After several warnings and numerous outbursts before the jury at his trial for assault, grand larceny, and reckless endangerment-including profanities directed at the judge-the court removed the defendant and continued the trial. ${ }^{174}$ On appeal, the court

173. See Davis v. Grant, 532 F.3d 132 (2d Cir. 2008) (ruling that defendant's Sixth Amendment right to counsel was not violated when he was removed from trial for disruptive conduct in absence of appointed standby counsel).

174. Id. at $136-37$. 
upheld the decision to continue with the trial despite the fact that the defendant was not present at trial and had no counsel to represent him. ${ }^{175}$

Although the appellate judges affirmed the conviction, they took care to underscore that their decision turned on the specifics of that case, thereby undermining arguments that it could serve as future precedent. ${ }^{176}$ In a somewhat unconventional move, perhaps reflecting the court's discomfort with its decision, the Second Circuit explicitly requested in its opinion that the U.S. Supreme Court should clarify the extent to which disruptive behavior constituted a waiver of the right to appear pro se and whether it was mandatory upon a lower court to appoint standby counsel for the duration of the trial. ${ }^{177}$ Perhaps the state of the law on these issues is somewhat unsettled, even if the idea is obvious that a selfrepresenting defendant acting in bad faith should not be rewarded with more grants of even greater liberties.

A stronger precedent exists within the U.S. for defendants choosing to represent themselves and then voluntarily remaining absent for the duration of trial. This scenario happened twice in the Second Circuit in the cases of Clark v. Perez, ${ }^{178}$ as well as famously in U.S. v. Torres. ${ }^{179}$ In both cases, the defendants chose to leave the court in order to further political ideologies, when they tried to deny the legitimacy of the court's authority to conduct the trial. In both cases, the court proceeded without appointing amicus curiae or standby counsel to protect the defendants' interests, and the jury found both defendants guilty of all charges.

In civil law and common law systems, there are typically requirements that defendants are present at trial, even though the former system is more flexible in that regard. At the regional level, the European Court of Human Rights has affirmed the rights of defendants to be present at appellate proceedings in addition to the criminal trial. ${ }^{180}$ It is a difficult problem when the defendant, as well as when all legal counsel, is either absent or removed from the court given how essential representation is to the concept of a fair trial. As international criminal procedures mature, there will likely be a swing towards the civil law. That trend is already discernible. Two different sides opposing one another are presumably necessary for the largely adversarial process presently existing to work. The international criminal justice system has not yet been willing to proceed with a trial where there was no one

175. Id. at $138-39$.

176. Id. at 149 .

177. Davis, 532 F.3d at 150.

178. Clark v. Perez, 510 F.3d 382, 387 (2d Cir. 2008).

179. Torres v. United States, 140 F.3d 392, 397 (2d Cir. 1998).

180. Helmers v. Sweden, 212 Eur. Ct. H.R. 3, I33 (1991), available at http:/hudoc.echr.coe.int/sites/eng/pages/search.aspx?i=001-57701. 
present to represent the interests of the accused. However, courts in the United States, Canada, ${ }^{181}$ Britain, and other common law jurisdictions have taken this step on occasion. But, unlike those courts, the international tribunals should be careful in that domain and try to remain true to the "interests of justice" standard. They must hold strictly to the idea that the fairness of the trial comes before all else, despite the increasing pressures to swiftly complete cases and or to close down.

\section{CONCLUSION}

The international criminal law has come a long way in the last few decades. In a recent open session at the ICTY on July 4, 2011, the Trial Chamber in the Mladic case, within just an hour in court, denied a request to give the defendant more time to review the indictment and supporting evidence before entering a plea, denied a request by counsel to withdraw due to a lack of communication with the accused, denied a request by the defendant to delay the trial until his counsel of choice could be assigned, removed the defendant from court for disruptive behavior, and continued entering pleas for the defendant after he was removed. ${ }^{182}$ All of these decisions occurred without the court-appointed duty counsel raising a single protest or caution regarding the court's actions. $^{183}$

This is a remarkable transformation from the early case law discussed in this article granting extensive delays to ensure that all of the defendant's rights were respected. The Šešelj court, for example, allowed the defendant to direct its rulings regarding the assignment of counsel rather than attempting to continue the trial without him being present. ${ }^{184}$ The approach in that case is reflective of a recent trend in decisions issued at international tribunals. Since the heavily criticized handling of the Milošević trial, international courts have steadily become stricter in dealing with attempts by defendants to upset the continuity of trial. Earlier in the days of the international tribunals, interest in the appearance of fairness trumped expediency in nearly every decision the court issued. With trials at the ICTY and ICTR wrapping up, however, courts have learned how to deal with frivolous attempts by the accused to cause delays while at the same time acknowledging and permitting legitimate exercise of their statutory rights. ${ }^{185}$ A much higher importance

181. R. v. Bitternose, [2009] SKCA 54 ๆ 97, 331 Sask. R. 19 (Can.).

182. See Prosecutor v. Ratko Mladić, Case No. IT-09-92-I, Transcript of Record (Int'l

Crim. Trib. for the Former Yugoslavia July 4, 2011).

183. See id.

184. See Šešelj, Decision on Appeal against Trial Chamber's Decision (No. 2) on

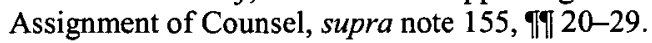

185. See POCAR, supra note 37 , at 8. 
is now being placed on finishing the mission of the tribunals and completing the administration of justice for the crimes committed.

There is more to the paradigm shift than simply wanting to complete the proceedings. After Milošević embarrassed the tribunal with his antics-and after his death, which meant that no formal judgment could be pronounced on his guilt or innocence-there was a definite public backlash against the freedom he was granted by the ICTY. The results of this backlash may well be reflected in the STL Statute, which allows for the trial of accused in absentia. These types of changes perhaps reflect lessons learned and the belief that firmer positions may be necessary during court proceedings as more and more international criminal trials are held. This paradigm shift, which speaks to both the need to improve the efficiency of trial procedures and the refusal to bow to the whims and caprices of manipulative and clever accused persons, has already been seen for decades in national criminal law. It is a welltrodden path. At the same time, in the international courts, these changes will raise new concerns about the need to balance the competing interests at stake and to maintain the integrity and fairness of trials for those accused of serious international offenses. ${ }^{186}$

The more stringent controls, and especially the in absentia provisions of the STL Statute, are perhaps indicative of a steady rise of civil law principles within international law. This gravitational pull is perhaps also reflective of global changes in common and civil law systems. There has been scholarly documentation of the steady convergence of the two types of systems recently. ${ }^{187}$ Many of the distinguishing features of each system have been slowly adopted by countries of the opposing system, with a set of best practices emerging in those jurisdictions. ${ }^{188}$ These developments may lead one to believe that systems of criminal justice at both the national and international level are finally "getting it right," but there is still much to learn, and future international tribunals would do well not to forget about upholding the interests of justice in each decision.

One important element that has yet to be incorporated into international justice is the principles from alternative legal systems. Both the civil and common law traditions have a largely "Western" background that excludes traditional African, Chinese, Indian, Islamic, and many other legal traditions and beliefs. ${ }^{189}$ How the major criminal

186. See Jenks, supra note 143, at 57; Williams, supra note 3 , at 553.

187. See, e.g., Salvatore Mancuso, The New African Law: Beyond the Differences Between Common Law and Civil Law, 14 ANN. Surv. INT'L \& COMP. L. 39, $42-43$ (2008); POCAR, supra note 37, at 1.

188. See Mancuso, supra note 187, at 42; POCAR, supra note 37 , at 1 .

189. Mancuso, supra note 187 , at 43. 
justice belief systems can better adapt to situations where non-western notions of justice predominate is an unsettled question. This question, like all those facing ad hoc criminal tribunals now and others yet to exist, requires a careful weighing of rights and interests. Some of those systems emphasize more conciliatory and rehabilitative approaches, and the jury is still out on whether those approaches are appropriate for application in international criminal trial contexts.

If nothing else, this article's comparative law discussion of how courts handle the role of counsel should have illuminated the many different perspectives through which each decision at the international court can be seen. Courts have to consider the fundamental rights of the defendant guaranteed by the rules of the court, the interests of the victims looking for justice, the finding of truth, fair and expeditious justice, the importance of an evidence-based trial, and the possible contributions to national healing.

When considering what lessons the international courts should draw from common law systems, civil law systems, and their own unique experiences, the aim to balance rights may well be the key, depending on the factual scenario in each case. As the international criminal law continues its lofty pursuit to "end impunity," it is unlikely that any single panacea, such as allowing trials in absentia, will determine the success or failure of the provision of international justice. There is no one size fits all solution. If international tribunals apply such provisions, keeping in mind the interests of justice, the accused as well as the victims, international justice will likely come out farther ahead.

As evidence of this truth, consider the cases discussed in this article. Despite alleged gaffes in judgment at the Milošević, Šešelj, and Barayagwiza trials, the ICTY and ICTR have been largely successful in fairly prosecuting those responsible for some of the most gruesome crimes, and no one has substantially contested the legitimacy of those convictions. It is perhaps too soon to judge how history will ultimately measure the success of the ICTR, ICTY, SCSL, and the STL. What is clear is that the international community has saddled these tribunals with an exceedingly difficult task, one that requires a careful balancing of rights that no amount of rulemaking or statutory provisions will easily solve. 
